\title{
Competition and Resource Partitioning in Three Social Movement Industries ${ }^{1}$
}

\author{
Sarah A. Soule \\ Cornell University \\ Brayden G King \\ Northwestern University
}

Drawing hypotheses from resource mobilization and resource partitioning theories (RMT and RPT), this article examines how interorganizational competition and social movement industry (SMI) concentration affect the level of tactical and goal specialization of protest organizations associated with the peace, women's, and environmental movements. Additionally, the article examines how specialization affects the survival of these organizations. By and large, the findings are commensurate with the expectations of RMT and RPT. Results indicate that interorganizational competition leads to more specialized tactical and goal repertoires. Concentration in the SMI also leads to specialization, but this is only true for less established organizations. Results also indicate that tactical and goal specialization decrease organizational survival, unless the industry is highly concentrated.

\section{INTRODUCTION}

Social movements are rarely unified phenomena; instead, they comprise organizations that vary with respect to objectives, strategies, and tactics (Gerlach and Hine 1970; Haines 1984; Benford 1993). Some social movement organizations themselves utilize diverse tactics and/or articulate various goals, while others are far more specialized.

For example, many historical accounts discuss the wide variety of or-

\footnotetext{
${ }^{1}$ This research was supported by grants from the National Science Foundation (SBR9709337, SBR-9709356, and SES 9874000) and from the University of Arizona's Vice President for Research Small Grants Program. We thank Doug McAdam, John McCarthy, and Susan Olzak for their role in collecting the data used for this project. Direct correspondence to Sarah Soule, Department of Sociology, Cornell University, Uris Hall, Ithaca, New York 14853. E-mail: ss31@cornell.edu
}

(C) 2008 by The University of Chicago. All rights reserved. 0002-9602/2008/11306-0003\$10.00

1568 AJS Volume 113 Number 6 (May 2008): 1568-1610 


\section{Social Movement Industries}

ganizational tactics and goals associated with the civil rights movement (e.g., Goldman 1969; Gerlach and Hine 1970; McAdam 1982; Haines 1984; Morris 1984). The National Association for the Advancement of Colored People (NAACP), for instance, was founded in 1909 and initially tended to focus on strategies designed to change public opinion about civil rights. In 1930, a separate wing of this organization, the NAACP Legal Defense Fund, was founded to raise money explicitly for legal activism (e.g., lawsuits to challenge segregation practices). Also within the civil rights movement, the Congress of Racial Equality (CORE) emerged from the Fellowship of Reconciliation and utilized a variety of different tactics directed at challenging segregation. In 1960, the Southern Christian Leadership Conference (SCLC) was pressured to support the formation of a new organization, the Student Nonviolent Coordinating Committee (SNCC), which was intended to use more radical and visible forms of direct action than SCLC typically did. Existing alongside these organizations were movement "halfway houses" (Morris 1984), such as the Highlander Folk School (Morris 1984; Edwards and McCarthy 1992), which helped to build and sustain the collective identity of civil rights activists. While this is certainly not an exhaustive list of all civil rights organizations, this discussion illustrates that while there may be a broad, shared goal among a set of social movement organizations, there are also important differences between these organizations with respect to tactics used and goals articulated. ${ }^{2}$

Differences between organizations with respect to tactics and goals lead to specialization at both the organizational and movement levels. The NAACP Legal Defense Fund is an example of how an organization can specialize; during the civil rights era, its main tactic was legal activism and its primary goal was to end segregation. Organizational specialization, in turn, contributes to movement-level specialization. When we consider the entire set of civil rights movement organizations, we can conceptualize the level of specialization as a characteristic of that set of organizations (rather than of any single component organization).

This observation derives from the early work of McCarthy and Zald (1977), who emphasize the need for social movement scholars to concentrate on both individual social movement organizations (SMOs) and the broader configuration of organizations that comprise the social movement

\footnotetext{
${ }^{2}$ This discussion dovetails with Haines's (1984) description of the various factions (e.g., moderate and radical) of the civil rights movement. For a discussion of the variation in tactics and goals used by organizations within a different movement, see Benford's (1993) description of radical, moderate, and liberal organizations within the nuclear disarmament movement in Austin, Texas.
} 
American Journal of Sociology

industry (SMI). ${ }^{3}$ Within a given SMI, SMOs frequently interact: they share personnel, office space, and information, collectively learn new tactics, join in coalitions, and so forth (Zald and McCarthy 1980). The interaction among SMOs has consequences for both the overall level of tactical and goal specialization of the SMI and for the level of specialization of any of the component organizations.

One form of interaction between SMOs that is not well understood is competition for resources (Zald and McCarthy 1980). Although we would like to think that SMOs in an industry cooperate in order to achieve a common goal, in reality SMOs often compete with each other for limited resources (Zald and McCarthy 1980; Koopmans 1993). ${ }^{4}$ Many have acknowledged that SMOs compete for participants' contributions of money, time, energy, and skills (e.g., Zald and McCarthy 1980; McCarthy and Zald 2001) and for symbolic goods, such as prestige (e.g., Benford and Zurcher 1990), but relatively few scholars have attempted to understand the effects of interorganizational competition on social movement organizational processes (but see Koopmans 1993; Minkoff 1993, 1994, 1995, 1997, 1999; Olzak and Ryo 2007).

What effect does competition have on SMIs and SMOs? Some social movement scholars draw on organizational ecology (Hannan and Freeman 1989) to examine how competition between SMOs impacts industrylevel changes. For example, Minkoff (1993, 1994, 1995, 1997, 1999) examines how competition affected founding and disbanding rates of organizations in the women's and ethnic civil rights movements. And Olzak and Ryo (2007), using a subset of Minkoff's data on black civil rights organizations, examine how levels of competition among these organizations affected the overall level of tactical and goal diversity of the civil rights movement industry. Finally, Koopmans (1993) examines how interorganizational competition led to the radicalization of tactics among "new social movements" in West Germany.

\footnotetext{
${ }^{3}$ According to McCarthy and Zald (1977, p. 1218), an SMO is a "complex, or formal, organization which identifies its goals with the preferences of a social movement or a countermovement and attempts to implement those goals." An SMI is the collection of all SMOs "that have as their goal the attainment of the broadest preferences of a social movement" (p. 1219). One might think of the SMI as the organizational analog of a social movement, which to McCarthy and Zald (p. 1217) is the "set of opinions and beliefs in a population which represents preferences for changing some elements of the social structure and/or reward distribution of a society." McCarthy and Zald also define the social movement sector (SMS) as the aggregation of all SMIs in a particular place at a particular time. Throughout this article, we use McCarthy and Zald's definitions of the social movement, SMO, SMI, and SMS.

${ }^{4}$ It is beyond the scope of this article to examine organizational cooperation, but this is another important form of organizational interaction. Future research should examine how cooperation impacts organizational specialization as well as sustainability.
} 
This work emphasizes the important insight from organizational ecology that "social changes affect the mix of organizations in a society" (Hannan and Freeman 1989, p. 52; emphasis in original). Minkoff, Koopmans, and Olzak and Ryo all study how various characteristics of an SMI drive changes in that population of organizations. In particular, they are interested in understanding how interorganizational competition affects the character of a social movement industry (or industries)—Minkoff by studying how competition affects founding and disbanding rates of SMOs in two industries, Olzak and Ryo by studying how competition affects the level of diversity in an industry, and Koopmans by studying how competition affects radicalization of tactics in several industries.

Beyond this, however, there has been little empirical work on the question of how competition between SMOs impacts organization-level processes, despite the fact that McCarthy and Zald's (1977) original hypotheses about the dynamics of SMIs call for such an approach (see also Zald and McCarthy 1980). In other words, work on interorganizational competition has examined the effects of competition on the character of the SMI, but not the effect of competition on individual SMOs.

This article examines how competition between SMOs in three different SMIs affects two important organizational processes: specialization and survival. We first assess arguments put forth by resource mobilization theory (RMT) and resource partitioning theory (RPT) about how interorganizational competition and the level of concentration within a given SMI affect the levels of tactical and goal specialization of individual organizations within that industry. Following this, we ask how a given organization's level of tactical and goal specialization affects its chances of survival, net of and in combination with the overall level of interorganizational competition in the SMI.

We use newspaper reports of public collective action events that took place in New York State between 1960 and 1986 to obtain data on protest organizations active in the peace, women's, and environmental movements. We have chosen to focus on these three SMIs because all three have been subject to SMI-level analyses in the past, but not to the kinds of questions we ask and the analyses we perform here (see Minkoff [1993, 1994, 1995, 1997, 1999] on the women's movement, Andrews and Edwards [2005] on the environmental movement, and Edwards and Marullo [1995] and Edwards and Foley [2003] on the peace movement). ${ }^{5}$ In addition, examining specialization and survival processes across three dif-

\footnotetext{
${ }^{5}$ Also note that organizations affiliated with these three movement industries are considered to have been some of the "most publicized" organizations during the period 1960-86 (Amenta, Caren, and Olasky 2005). Bearman and Everett (1993) also found them to be important industries across various periods.
} 
American Journal of Sociology

ferent SMIs gives us more confidence that our findings are not an artifact of one particular social movement and thus allows us to better contribute to the development of theory regarding these interorganizational processes.

The data we use include detailed information on organizational tactics and goals; thus, we are able to devise measures of the levels of tactical and goal specialization of each organization active in each of these three industries during the period 1960-86. We find that two measures of competition (SMI density and concentration) lead to tactical and goal specialization. In turn, we find that organizations with more specialized tactical and goal repertoires are less likely to survive, although the concentration of an SMI increases specialists' chances of survival. We conclude by discussing the implications of these findings for social movement and organizational studies.

\section{THEORETICAL BACKGROUND AND OUR ARGUMENT}

In their 1977 article, McCarthy and Zald simultaneously introduced the concepts of the SMO and the SMI and set in motion something of a sea change in social movement studies, from a focus on "collective behaviors" (e.g., rumors, fads, mobs, and panics) to a focus on the organizational and rational bases of social movements. Microlevel scholarship on social movements shifted from examining how deprivation and maladaptive impulses led individuals to join movements to examining how movements transform sympathizers or bystanders to participants or adherents. Scholars also became very interested in more meso- and macrolevel processes, particularly how organizations and organizational processes facilitate the procurement of resources essential to movement activity (see recent reviews of RMT in Edwards and McCarthy [2004] and McCarthy and Zald [2001]).

In addition to drawing attention to organizational processes, early RMT also highlighted interorganizational processes by defining both the SMI and the SMS. As described in note 3 above, the SMI is the collection of all organizations associated with a particular social movement, while the SMS is the collection of all organizations associated with all movements in a particular society. One might think of these two concepts as analogous to concepts in organizational ecology (Hannan and Freeman 1989): an SMI is the population of organizations seeking change associated with a particular social movement, while an SMS is the community of organizational populations seeking change across all movements (Hannan and Freeman 1977; Ruef 2000).

It is interesting to note that while the lion's share of research on social 
movements focuses on one particular movement (as in case studies of the civil rights or peace movement), there have been relatively few attempts to study entire SMIs - at least as originally defined by McCarthy and Zald (1977) to include all organizations working toward the goals and preferences of a particular movement. ${ }^{6}$ That is, although there are plenty of case studies of social movements, there are few studies of all of the organizations that make up these movements. ${ }^{7}$ Additionally, of those that have attempted to analyze all organizations within a particular SMI, few have attempted to examine how the character of the SMI affects organization-level processes. This is a shame, because some of the most interesting questions raised by McCarthy and Zald (1977) necessitate an understanding of the SMI and how SMI-level processes affect organization-level processes (see also Zald and McCarthy 1980).

One important organization-level process is specialization. Casual observations of SMOs associated with the same industry show that there is a great deal of variation with respect to what organizations do. Some organizations within an industry articulate multiple diffuse goals, while others are far more focused. For example, as shown by our data (described below), the Sierra Club typically sets very broad goals related to environmental protection, while Save Our Cumberland Mountains espouses much more specialized goals (e.g., reducing emissions of sulfur dioxide by the Tennessee Valley Authority). Similarly, some organizations use a variety of tactics, while others tend toward specialization. For example, in our data, the Real Alaska Coalition used four different tactics in one year, while Solar Action used a single tactic in that same period. However, specialization of SMOs remains largely unstudied in the social movement literature (although see King and Cornwall 2005). The question remains, What factors lead to variation within an industry with respect to organizational goal and tactical specialization?

Early RMT offers a number of important insights that are critical to understanding why it is that some SMOs have specialized goals and tactics. In particular, RMT hypothesizes that SMOs specialize so that they do not have to compete directly with one another (McCarthy and Zald 1977; Zald and McCarthy 1980). This hypothesis was based on insights from economists about specialization among firms. Under conditions of interorganizational competition, an organization differentiates its product

\footnotetext{
${ }^{6}$ Even fewer studies have attempted to examine entire social movement sectors (see Everett 1992). Studying the effects of interorganizational competition at the sector level is an important next step in this research.

${ }^{7}$ There are some notable exceptions: see McCarthy et al. (1988), Meyer and Imig (1993), Minkoff (1993, 1994, 1995, 1997, 1999), Edwards and Marullo (1995), Smith (1997, 2002, 2004, 2005), Brulle (2000), Kempton et al. (2001), Edwards and Foley (2003), and Andrews and Edwards (2005). These works are described in more detail below.
} 
American Journal of Sociology

from those of its competitors in order to capture a distinct segment of the market (Rosen 1974; Zald and McCarthy 1980; Shaked and Sutton 1982). In their original hypothesis, McCarthy and Zald (1977) argue that interorganizational competition is a function of the number of SMOs in the industry (but see their further discussion of perfect and imperfect competition in Zald and McCarthy 1980). The "products" that SMOs offer are tactics and/or goals, and each organization's hope is that by offering unique tactics and goals it may be able to appeal to a particular set of potential participants or benefactors (Gamson 1987).

In their original formulation, McCarthy and Zald (1977) also emphasize the importance of discretionary resources available at the societal level. When more resources are available to an existing SMI, competition within that industry is less intense. But during times of economic hardship, competition intensifies between organizations. Therefore, general levels of resource scarcity should also be associated with increasing specialization among SMOs.

An important and related argument is offered by RPT, a branch of organizational ecology that attempts to explain specialization in a population of organizations. RPT was originally developed by Glenn Carroll (1985) to study the tendency of newspaper markets to be dominated by a few very large generalist newspapers, but with smaller, more specialized newspapers existing simultaneously when markets are highly concentrated. ${ }^{8}$ According to RPT, older, better-established, and larger firms have a competitive advantage over smaller, newer, and less well-established firms because of economies of scale, which allow the larger firms to expand their products and resource base at a lower cost than smaller organizations. ${ }^{9}$ As a result, in mature industries larger organizations dominate, which leads to increasing concentration and a higher level of generalism among surviving organizations. But at the same time, as fewer, more generalist organizations dominate the industry, specialists are able to emerge and thrive on the fringes of the market by offering specialized products. Resource partitioning is the term for this division of the market into heterogeneous resource bases.

Key to arguments about the effects of resource partitioning on organizational specialization is the level of market concentration, which can be thought of as a different type of competition than is created by density

\footnotetext{
${ }^{8}$ For additional studies of resource partitioning in a variety of different industries, see Barnett and Carroll (1987), Carroll and Swaminathan (1992, 2000), Swaminathan (1993, 2001), Wade (1996), and Freeman and Lomi (1994).

${ }^{9}$ McCarthy and Zald's formulation of RMT also accounts for the "cost reducing mechanisms and structures" (1977, p. 1216) that give certain SMOs competitive advantages. Thus, the emphasis of RPT on incumbents' cost advantages over newcomers is compatible with RMT.
} 
(Carroll and Hannan 2000). An industry is highly concentrated when only a few organizations take up a majority share of the industry's resources (see also Zald and McCarthy 1980). When an industry is highly concentrated, specialists are able to thrive because they are not in direct competition with generalists. However, when concentration is lower, small specialists are forced to compete with generalists, and they typically do not fare well in this contest because of their scale disadvantage.

There are obvious similarities between the core arguments of RMT and RPT. In particular, both predict that the level of competition in an industry affects the level of specialization of organizations therein. But there are key differences between the hypotheses offered by each of these two theories. First, RMT is chiefly concerned with what happens to specific organizations under conditions of competition, while RPT, as an ecological argument, is concerned with what happens to the mix of organizations in a population. Underlying assumptions about the nature of organizational change determine this difference in analytical focus. RMT assumes that organizations are adaptive and alter their level of specialization according to competitors' behaviors (Minkoff 1999). RPT assumes that organizations are inertial and do not rapidly innovate, and so organizational change occurs at the population level through selection. So, while both theories predict that specialization is associated with competition, RMT predicts that organizations change what they are doing when confronted with competitive pressures, while RPT predicts that specialist organizations will have survival advantages when the industry is highly concentrated.

The second difference between the two theories is that RMT is chiefly concerned with competition as a function of the size (or organizational density, to use the vocabulary of organizational demographers such as Carroll and Hannan [2000]) of the SMI, while RPT suggests that market concentration changes the nature of competition such that industries with high concentration can have two distinct segments of competing organizations: generalists and specialists. ${ }^{10}$ Thus, in a highly concentrated industry, large organizations compete with one another as generalists, while specialists compete with one another in a partitioned segment of the industry.

The branch of organizational sociology most concerned with competition, organizational demography, supports the notion that density and concentration represent different forms of competition (Carroll and Han-

${ }^{10}$ It is interesting to note that Zald and McCarthy (1980) begin to discuss industry concentration as a special form of competition, but to our knowledge social movement scholars have not (yet) picked this up and noted the synergy between their arguments and RPT. 
American Journal of Sociology

nan 2000; Hannan and Carroll 1992). Density is assumed to have a nonmonotonic relationship with competition: competition increases at a growing rate with higher levels of density. Concentration, on the other hand, suggests the existence of a partitioning of competition into distinct market segments, as discussed above.

Drawing from these two theoretical traditions, we test several central hypotheses about how these two SMI-level indicators of competition, density and concentration, shape organizations' tactical and goal specialization. Following RMT, we argue that as organizational competition in an SMI increases, SMOs will adopt more specialized tactical repertoires and espouse more specialized goals. ${ }^{11}$ Individual SMOs are aware of the tactics and goals of their peers and will attempt not to reproduce others' efforts. Instead, increasing competition makes SMOs attempt to find some unique way to address their particular issue or to frame their goal or claim. Strategies of tactical and/or goal specialization allow SMOs in the same industry to draw on a shared resource base, such as membership, without having to worry about members tiring of belonging to multiple SMOs.

RMT also leads us to predict that when there are fewer resources at the societal level, SMOs will adopt more specialized tactical repertoires and espouse more specialized goals. During times of recession, resource scarcity, or other economic hardship, there is more intense competition between organizations within an SMI and this in turn leads SMOs to try to find unique niches that protect them from direct competition with other SMOs.

Third, we hypothesize that the effects of competition on specialization will not be uniform across all SMOs in an SMI. In a mature SMI, organizations become larger and are more able to adopt new tactics and claims without exhausting their existing infrastructure and resources (Carroll 1985; Swaminathan 2001). Incumbents multiply tactics and claims by incorporating those used by surrounding specialists and are able to do this with relative ease because they already have a substantial resource base on which to draw. The tendency for incumbents to become more complex and sweeping in scale leads to the creation of robust identities that appeal to the needs of a variety of movement activists and resource inputs (Carroll and Swaminathan 2000; Swaminathan 2001). For example, incumbent SMOs may use their dense networks to coordinate large-scale protests at the same time that they conduct sophisticated public relations campaigns and lobby individual legislators. Therefore, we argue that not all SMOs will specialize; rather, large incumbent organizations will be

${ }^{11}$ See Haider-Markel (1997) for a similar hypothesis with respect to interest organizations. 


\section{Social Movement Industries}

less likely to specialize, while smaller, less well-established organizations will be more inclined to do so.

Readers may ask why it is that specialist organizations exist if generalists can perform the same tasks and represent the same grievances at a lower coordinating cost, as we have just noted above. RPT suggests that specialist organizations sometimes do not thrive because of the functionality of their structure and product. In fact, the organizational outputs of generalists are often of a higher quality than (or at least equal quality to) those of specialists. For example, macrobrewers proved equally as effective at producing custom beer as microbreweries (Carroll and Swaminathan 2000). Macrobrewers, however, faced an identity constraint that inhibited their ability to move into the specialty beer market. Customers seeking specialty brews did so because the product conformed to their identity as sophisticated consumers. The status associated with consuming in a boutique brewery was as much sought after as the beer itself.

Similarly, movement activists often adhere to strict personal identities (Stryker 2000) that conflict with the organizing efforts of large-scale, bureaucratized SMOs. A certain segment of the activist (or donor) population might wish to "act locally," or at least to dissociate itself from the largest, most prominent SMOs in a particular industry. Although specialist and generalist SMOs both find themselves fighting for the same social causes, they target specific identity segments of the movement resource base. The emergence of specialist SMOs, therefore, most likely occurs in highly concentrated industries in which entrenched incumbents already exist.

Once we have examined how industry competition and concentration affect an organization's tactical and goal specialization, we then look at how an organization's level of specialization (net of and in combination with the overall level of competition and concentration within the industry) impacts its chances of persistence or survival. Based on RPT, we expect that SMOs that adopt a more generalist strategy will be more likely to persist; generalists have survival advantages because diversification spreads out their risk (Singh and Lumsden 1990; Edwards and Marullo 1995). ${ }^{12}$

However, we also argue that under certain conditions, generalists' survival advantages may be weakened. Specifically, on the basis of RPT, we expect that generalist and specialist organizations' survival rates will respond differently to high levels of industry concentration; in concentrated industries, we expect that specialists' rate of survival increases, while

\footnotetext{
${ }^{12}$ Note that, contrary to this hypothesis, Gamson (1975) found that SMOs with more specialized goals were more likely to survive. As we discuss in more detail below, our analysis allows us to examine the conditions under which specialized SMOs will have survival advantages over generalist SMOs.
} 
American Journal of Sociology

generalists' rate decreases. Under conditions of industry concentration, specialized organizations may be better at recruiting and retaining members since they are better able to offer benefits (Olson 1965) tied to specific social movement identities. Much like microbreweries thriving in concentrated markets by offering products that are differentiated from those of macrobrewers, specialized movement organizations offer a product more resonant with particular activist identities and preferences. Generalist organizations, in contrast, will lose their scale advantage in concentrated industries. We do not suggest that generalist organizations will cease to exist; rather, in highly concentrated industries, their disadvantage in mobilizing identity-specific protesters will weaken their chances of remaining in the pool of protesting organizations, and they may opt to focus their efforts on other kinds of movement activity instead.

\section{RESEARCH DESIGN}

Defining the Social Movement Industry

Why have so few scholars examined the dynamics of competition between SMOs within SMIs? First, while McCarthy and Zald (1977) offer a clear working definition of the SMI, in empirical practice it has not been easy to operationally define an industry because it is not always clear precisely which organizations should be included; in other words, the boundary of an SMI is not always intuitively obvious. ${ }^{13}$ At first glance it may seem obvious that, since a given SMI is defined by its social movement, one might include any organization working toward change in that area. However, the real problem lies in defining what "working for change in an area" means and, on top of this, in finding data sources on such organizations. Despite these difficulties, there are some exemplars in the literature.

The classic study of SMIs was conducted by Minkoff (1993, 1994, 1995, 1997, 1999), who examined all U.S. organizations in the Encyclopedia of Associations connected with the women's and race and ethnic civil rights movements. While this strategy allowed Minkoff to identify organizations working toward change associated with a variety of different social movements, coding these national-level directories provided information only on those organizations that self-reported to the Gale Research Company (after being identified by Gale staff or requesting inclusion). As such,

\footnotetext{
${ }^{13}$ This issue is akin to problems faced by organizations scholars who grapple with how to define organizational populations, fields, and industries (Hannan and Freeman 1989) and by political sociologists, more generally, who attempt to define policy domains (Laumann and Knoke 1987).
} 


\section{Social Movement Industries}

certain organizations may be underrepresented, particularly protest organizations (Minkoff 1999, p. 1678; 2002, p. 267). Nonetheless, Minkoff's clever research design has been replicated by others. For example, Smith (1997, 2002, 2004, 2005) used the Yearbook of International Associations to collect data on transnational SMOs associated with nearly 40 different SMIs. Others, such as Edwards and Marullo (1995), Brulle (2000), Kempton et al. (2001), Edwards and Foley (2003), and Andrews and Edwards (2005), have used various organizational directories in combination with surveys, in-depth interviews, and Internal Revenue Service (IRS) documentation to collect data on organizations within a single SMI (often in a limited geographical area or two).

Aside from relying on organizational directories, scholars have used a variety of other archival sources. For example, McCarthy et al. (1988) used chapter rosters of national organizations to obtain data on state and local organizations in a single SMI (the anti-drunk driving movement). Fernandez and McAdam (1988) used applications to the Freedom Summer project to identify SMOs associated with the New Left movement industry in two different campus communities (Madison, Wisconsin, and Berkeley, California). Finally, Rosenthal et al. (1985) used biographical profiles of prominent women reformers in New York State to track organizations active in a variety of different SMIs in the 19th century.

In this article, we employ a different strategy. Specifically, we build on the strategy used by Everett (1992) and Bearman and Everett (1993) to, in their case, operationally define the social movement sector. We argue that an SMI comprises all organizations that participate in public protest events that are associated with the same general goal for change (e.g., to promote peace, women's rights, or the environment), as reported in newspaper accounts of protest events in a given area of the country. Participation in a protest event can mean anything from sponsoring (or cosponsoring) the event to organizing the event to providing participants and resources. The essential criterion is that the organization in question be explicitly named as somehow facilitating the execution of the protest event. This approach uses information on what organizations do (i.e., participate in public protest events) to define them as part of the SMI, rather than using preexisting directories of organizations, activist accounts, or activist biographic profiles. ${ }^{14}$ Specifically, by collecting data on all public protest events associated with a particular set of SMIs and determining the names of organizations participating in these events, we are able to define the organizations that make up each SMI.

There are three important issues to note regarding this operational

${ }^{14}$ Note that we are not criticizing these other data sources but rather offering an alternative way to operationally define the SMI. 


\section{American Journal of Sociology}

definition. First, as should be clear, we define SMOs on the basis of one function of such organizations: participation in public protest events. To be sure, SMOs perform many other functions (e.g., lobbying, litigation, counseling, and teaching). But we argue that public protest is a key function of SMOs, and so we use this as our criterion for including an organization in an SMI. ${ }^{15}$

Second, it is important to note that by defining the SMI in this way, we include groups that are not what we might typically define as "social movement organizations." For example, churches and their members often participate in public protest events, but we would not necessarily consider churches to be SMOs. By defining the sector as comprising all organizations that participate in public protest events, we release ourselves from the bounds of essentialist definitions. However, for simplicity and ease of interpretation, we will continue to use the acronym "SMO" to refer to the organizations we study.

Finally, defining the SMI in this way also offers a different way to classify an organization into the appropriate industry, based on the issue about which it is protesting and the year in which it does so. For example, the organization Women Strike for Peace appears in our data at close to 50 protest events related to the peace movement (spanning the period 1961-75) and in two protest events related to the women's movement (1967-71). However, this organization is not listed at all as a peace or women's association in the Encyclopedia of Associations in some years in which it participated in protests (e.g., 1961), although it is listed in other years. ${ }^{16}$

\section{Data Source}

As noted above, like Everett (1992) and Bearman and Everett (1993), we collect data on organizations active in protests connected with the peace, women's, and environmental movements from newspaper reports of protest events. These data are collected from daily editions of the New York Times (NYT) as part of a larger research project initiated by McAdam, McCarthy, Olzak, and Soule (see McAdam and Su [2002], Earl, Soule,

\footnotetext{
${ }^{15}$ This is consistent with Tilly (2004), who maintains that this repertoire of tactics (marches, rallies, demonstrations, etc.) is a primary feature that distinguishes social movements from other forms of contentious politics, and with Tarrow (2001), who argues for a behavioral definition of social movements. But note that our definition excludes organizations that choose not to participate in public collective action events.

${ }^{16}$ In a small number of cases (like that of Women Strike for Peace), an organization participated in events connected with different industries in the same year. In such cases, we classified the organization in the industry in which the majority of its events took place.
} 


\section{Social Movement Industries}

and McCarthy [2003], Van Dyke, Soule, and Taylor [2004], Soule and Earl [2005], Earl and Soule [2006], King and Soule [2007], and King, Bentele, and Soule [2007] for descriptions of the larger project). While the broader database includes protest events that happened all over the country from 1960 to 1986, we limit our analysis to events that occurred anywhere in the state of New York during that time period. We limit the analysis to a single state for two reasons. First, the $N Y T$ 's coverage of local protests is more complete than its coverage of national protests (McCarthy, McPhail, and Smith 1996; Oliver and Myers 1999; Oliver and Maney 2000; Swank 2000; Davenport and Ball 2002; Earl et al. 2004). Second, limiting our analysis to New York is also in line with organizational demography, which sees resource niches as being geographically heterogeneous (Hannan and Freeman 1989; Freeman and Audia 2006) and follows previous resource partitioning studies in analyzing a geographically specific industry (e.g., Carroll 1985).

In order to be included in our analysis, events also had to meet several other criteria: (1) more than one person had to participate in the event, since our concern is with collective action; (2) participants must have articulated a claim associated with either the women's, environmental, or peace movement; (3) the event must have happened in the public sphere; and (4) at least one organization must have been named as present at the event. While most of our events targeted some level of state government, events could also target private entities (e.g., corporations, religious organizations) or the broader public (see the description of targets in Van Dyke et al. [2004]). As noted above, we code participating organizations from reports of these events in New York State.

Newspaper reports on collective action events are one of the most frequently used forms of data in the field of social movements, and the field has learned a great deal from studies employing such data (see Earl et al. 2004 for a review). In fact, McAdam and Su (2002, p. 704) note that the analysis of protest event data culled from newspapers is a "methodological staple" in social movement studies and that many of the "classical empirical works in the field" use newspaper data. Because of the popularity of newspaper data in the study of collective action events, there have been many attempts to assess the potential biases associated with this source (see recent comprehensive reviews in Earl et al. [2004] and Ortiz et al. [2005]). In particular, studies have asserted that there are two main sources of bias in newspaper data: selection bias and description bias. Selection bias refers to the fact that not all protest events will be covered by a given newspaper and to the possibility that what is covered is not a random sample of all events that took place; such bias may vary over time (Mueller 1997). Description bias refers to the veracity of the reporting of events that are selected for coverage. In their extensive review 


\section{American Journal of Sociology}

of the literature, Earl et al. (2004) conclude that the type of event, its location, and the issue involved all impact its selection for coverage, but the "hard facts" of the event are generally accurately covered by newspapers.

The data collection design we use attempts to deal with these potential biases. First, as we note above, we examine only events (and organizations) in New York State, since we are using the $N Y T$ as a data source. This strategy reduces selection bias due to the geography of an event (McCarthy et al. 1996; Oliver and Myers 1999; Oliver and Maney 2000; Swank 2000; Davenport and Ball 2002; Earl et al. 2004). Second, unlike many prior studies using newspapers as a source of data on collective action events, we did not use an index of the $N Y T$ to identify events, nor did we sample days of the newspaper to code. Instead, we skimmed daily editions of the newspaper and identified all protest events that were reported. ${ }^{17}$ This strategy also reduces selection bias, by not introducing further sources of selection (such as, in this case, the researcher or the indexing procedure). Finally, because for this article we draw on the "hard facts" of the events (as will be described in detail below, we use data on tactics used, goals articulated, organizations present, and policing) and not on "soft facts" (such as opinions on the issue being protested), we are confident that the accuracy of our data is acceptable.

Despite our measures to reduce bias, critics will likely fault our use of newspaper data to identify protesting organizations. We ask that such critics consider the alternatives, which we describe above, and note that virtually all alternative sources for data on protesting organizations (or SMOs) come with their own biases. For example, directories tend to overreport larger, more established organizations and to underreport protest organizations (Minkoff 2002), and the IRS holds records only for those organizations that file with it (Brulle 2000). ${ }^{18}$ Fundamentally, to adequately assess the extent of the bias inherent in any of these data sources, one would need a separate data source on the entire population of all protesting organizations-something that simply does not exist. Thus, we ask critics to accept our data source, knowing that it (like other sources) likely has some bias, which we have attempted to reduce to the best of our ability.

\footnotetext{
${ }^{17}$ Research assistants then content-coded these events, achieving intercoder reliability rates that were consistently at or above $90 \%$ agreement.

${ }^{18}$ As a reliability check, we cross-referenced our list of protesting organizations in our three SMIs with those listed in the Encyclopedia of Associations for a random set of years. Overlap ranged from $56 \%$ to $79 \%$, depending on the industry and the year. It is interesting to note that one of the things this cross-check showed us is that Minkoff (2002) is correct: the Encyclopedia tends to underreport local organizations and protest organizations.
} 


\section{Social Movement Industries}

\section{Dependent Variables}

From this record of all protest organizations active at New York State protest events reported in the NYT between 1960 and 1986, we are able to define several dependent variables. First, drawing from information on the array of tactics and goals used each year by each SMO in the three SMIs, we develop two dependent variables that are used in the analysis below. ${ }^{19}$ The first dependent variable is the level of tactical specialization, $L_{t s}$. To compute this measure, we first divide the number of tactics used by an organization in a given year by the total number of tactics used by all organizations in the SMI in that year. We then multiply this value by -1 for ease of interpretation, since we are interested in specialization:

$$
L_{t s}=-1\left(N_{O R G} / N_{T O T}\right) .
$$

$N_{\text {ORG }}$ is calculated with the following equation:

$$
N_{\text {ORG }}=\sum_{i=1}^{N_{T O T}} c_{i O R G},
$$

where the value of $c_{\text {IORG }}$ is 0 if organization $O R G$ did not use tactic $i$ and 1 if it did. (Appendix A lists all of the tactics used by SMOs in the United States at protest events in the period 1960-86).

The second dependent variable is the organization's level of goal specialization, represented as $L_{g s .}$. To compute this measure, we first divide the number of goals articulated by an organization in a given year by the total number of goals articulated by all organizations in the SMI in that year. We then multiply this value by -1 , as we did above for tactical specialization:

$$
L_{g s}=-1\left(N_{\text {ORG }} / N_{\text {TOT }}\right) .
$$

$N_{\text {ORG }}$ is calculated with the following equation:

$$
N_{\text {ORG }}=\sum_{i=1}^{N_{T O T}} c_{i O R G},
$$

where the value of $c_{\text {iORG }}$ is 0 if organization $O R G$ did not use goal $i$ and 1 if it did. (App. B lists all of the goals articulated by organizations associated with the U.S. women's, peace, and environmental movements, as reported in the NYT in the period 1960-86.)

After analyzing protest organizations' tactical and goal specialization, we are interested next in understanding how an organization's level of

${ }^{19}$ Note that in our second analysis on organizational survival, these two dependent variables (tactical and goal specialization) are used as independent variables. 


\section{American Journal of Sociology}

specialization, net of and in combination with SMI competition and concentration, impacts its persistence as a protest organization. In other words, we use our dependent variables as explanatory variables for the persistence of an SMO in the pool of protest organizations. ${ }^{20}$ For this analysis, we assume that if an organization is reported as participating at an event at time ${ }_{1}$ but then never appears again in newspaper reports,

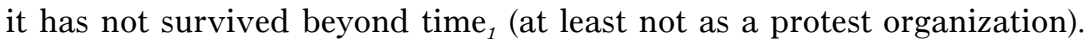
For our purposes, this organization no longer persists in the population of protest organizations. ${ }^{21}$ If an organization appears time and time again at events, we assume that it has survived as a protest organization between each appearance in our record. The mean duration of persistence in our data is 2.40 years (after the year of first protest), while the maximum is 19 years and the median is 2. This dependent variable, then, is a dummy variable for each organization for each year, coded 0 if the organization is engaging in protest in that year and 1 for the first year in which the organization fails to engage in some kind of protest. For example, if an organization participates in events in 1967, 1980, and 1985, we code 1986 as 1. (See app. C for data from three sample SMOs.) ${ }^{22}$

It might be argued that if an organization does not participate in protests for a long period of time, it has not really survived. We argue the contrary: as long as an organization returns to protesting after an interval of nonparticipation, we consider it to have survived. As observed by Taylor (1989), SMOs often undergo periods of abeyance in order to maintain the survival of the movement. The crucial criterion for survival or persistence here is whether an SMO is able to reorganize its membership

\footnotetext{
${ }^{20}$ In analyses not shown, we also examined whether or not the dependent variable in the second analysis (persistence) impacts an organization's level of tactical and goal specialization. While this effect was not significant in the models we ran, the sign on the coefficient was negative, suggesting that more persistent organizations are less likely to specialize.

${ }^{21}$ Note that this implies that an organization can survive as an organization though it ceases to participate in public protest events. If an organization changes strategies and decides not to participate in or sponsor protest events, while it continues to exist, for our purposes it has failed as a protest organization. This operationalization of survival is similar to the study designs of other ecological analyses (e.g., Rao 1994; Zaheer and Mosakowski 1997; Carroll and Swaminathan 2000).

${ }^{22}$ We experimented with some alternative specifications of the dependent variable in an effort to assure ourselves and readers that our coding decisions did not impact our results. First, we coded all cases that extended into the 1980s as right-censored (i.e., all protest organizations were right-truncated beginning in 1980). Second, we coded all cases that had extensive persistence times (beyond the ninety-fifth percentile) as right-censored. We ran all of the models presented further below in table 2 with these alternative specifications; the direction and magnitude of the main explanatory variables did not change greatly, and our main conclusions remained unchanged. Results are available from the authors upon request.
} 


\section{Social Movement Industries}

in order to protest once again. Although there may be some slippage in our operationalization of SMO survival, we believe this variable captures as accurately as possible the extent to which an SMO maintains its structure in order to survive to protest another day.

This mirrors Minkoff's (1993, 1994, 1995, 1997, 1999) strategy of inferring organizational survival from inclusion in the Encyclopedia of Associations. Like Minkoff's, our dependent variable measures the rate of organizational failure to protest, since we code it as 1 when the organization no longer protests (see Minkoff 1993, p. 899) Thus, a positive coefficient on a given term indicates that this variable increases the organization's failure to protest or failure to exist as a protest organization.

\section{Independent Variables}

Organizational tactical and goal specialization.-Our hypotheses about how SMI-level factors impact individual organizations' levels of tactical and goal specialization necessitate the measurement of two key concepts: organizational density (i.e., industry size) and concentration. To measure density, we constructed a yearly count of the number of organizations active in protest associated with each of the three SMIs. Figure 1 shows the yearly density of the three SMIs. In the models below, we also include a measure of density squared to test for the second-order effects of competition on organizational specialization.

It is reasonable to ask whether the patterns of industry size depicted in figure 1 are similar to other descriptions of these three SMIs. However, since we focus specifically on protest organizations in New York during this period, there really is not another source to which we can compare our figures directly. As Brulle (2000, p. 101) notes (with respect to the environmental movement industry), "The size of the U.S. environmental movement has never been measured accurately. There is little or no agreement on what constitutes a 'movement' organization, or on where the boundaries between the environmental movement and related movements (for example, animal rights) should be drawn." Thus, comparing our data to that of others is a bit like comparing apples to oranges. ${ }^{23}$

\footnotetext{
${ }^{23}$ For example, Edwards and Marullo (1995) and Edwards and Foley (2003) report substantially more peace organizations in the 1980s than we have. But it is critical to note that the data on which these authors rely cover far more than just protest organizations-their data include informal friendship groups and virtually any group working toward peace, not merely those that took part in protest events-and, of course, that these authors examine all such organizations in the entire United States (Edwards and Marullo 1995, p. 911). Similarly, Andrews and Edwards (2005) report on 738 environmental organizations in North Carolina, and Kempton et al. (2001) find 566 local environmental organizations in North Carolina and the Delmarva Peninsula.
} 
American Journal of Sociology

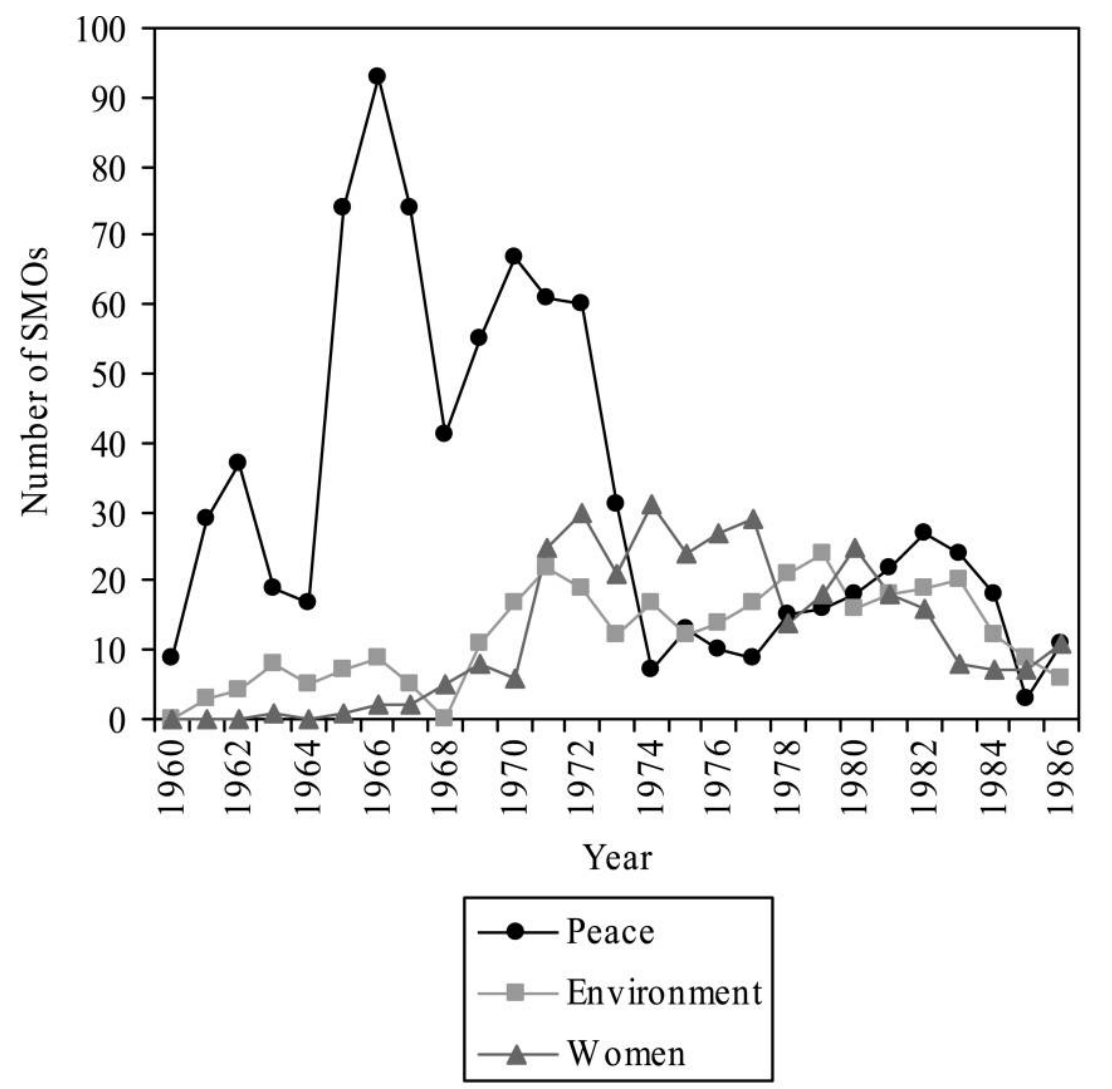

FIG. 1.-Yearly industry density in the peace, environmental, and women's SMIs

To measure SMI-level concentration, we use the Herfindahl-Hirschman index (HHI), which is a standard measure of market concentration. It is computed by summing the squared market shares of each organization competing in an industry:

$$
H H I=s_{1}^{2}+s_{2}^{2}+s_{3}^{2}+\ldots+s_{n}^{2},
$$

where $s_{i}$ is the market share of the $i^{t h}$ organization, and $n$ is the total

Although both of these studies show more environmental organizations than we have identified, these studies also include more than just protest organizations and are conducted after the end of our period of analysis. Nonetheless, it is important to note that the post-1970 increase in the density of women's protest organizations in New York mirrors a similar increase in the density of women's advocacy, cultural, service, and protest organizations at the national level, shown by Minkoff (1995, p. 62). 
number of organizations in the industry. ${ }^{24}$ For the purposes of this study, market share is protest share, which is computed yearly for each organization and is simply the number of protest events that an organization took part in in a given year, divided by the total number of protest events that took place that year in the organization's SMI. ${ }^{25}$

In models in which we include this SMI concentration measure, we also include the protest share variable to test for the argument that larger, more active organizations are less likely to specialize. RPT, as noted above, predicts that newer, less well-established organizations will be the ones to specialize. While our measure of protest share is not a measure of age, it is a measure of activity and thus might reasonably be seen as a proxy for level of establishment and, perhaps, age. We also include a dummy variable that is coded 1 when an organization's protest share is greater than the mean protest share of all organizations in a given year, in the particular industry to which the organization belongs.

Finally, we include an interaction term designed to test whether or not incumbent organizations in highly concentrated industries are less likely to specialize. According to RPT, older, more established organizations are more likely to be generalists and to be located closer to the center of the market, while newer, less established organizations are more likely to be specialists located on the fringes of the market. Thus, we expect to find a negative effect of this interaction term on the level of specialization. That is to say, the negative effect of incumbency (its main effect) on tactical and goal specialization will be amplified under conditions of high concentration.

Organizational survival.-In our analysis of SMO survival, as in that of organizational specialization, we are interested in understanding how industry-level dynamics of concentration and competition affect an organization's chances of survival as a protest organization. Thus, we include our yearly measures of competition and concentration as described above. However, we are also interested in understanding how an orga-

\footnotetext{
${ }^{24}$ In models not shown, we constructed an index of tactical overlap based on the procedures outlined by Olzak and Uhrig (2001, p. 704), in an effort to provide a third conceptualization of competition (in addition to density and concentration). Our index was fairly highly correlated with density $(.80)$ and produced the same results as models presented here.

${ }^{25}$ For example, in 1967, Students for a Democratic Society (SDS) was present at 15 different peace movement protest events. That year, there were 116 events associated with the peace SMI; thus, SDS's protest share for 1967 was .1293103. In other words, SDS was present at $12.93 \%$ of all peace movement events that took place in New York in 1967. In contrast, Veterans for Peace was present at only 2 of the 116 events in 1967 and thus had a protest share of .0172414 . After computing the protest share for each organization, each year, by industry, we summed the squared values of these to compute the HHI, as described above.
} 


\section{American Journal of Sociology}

nization's level of tactical and goal specialization affects its chances of survival. Therefore, we also include our measures of organization-level tactical and goal specialization described above as dependent variables.

The most important measures in our analysis of organizational survival or persistence, however, are two different interaction terms that we construct to test arguments about RPT. First, we include a statistical interaction term for the level of SMI concentration and the organization's level of tactical specialization, to test the argument that when concentration is high, the rate of survival of tactical specialists increases. Second, we include an interaction term for the level of SMI concentration and the organization's level of goal specialization, to see whether the chances of survival of goal specialists increase in highly concentrated industries.

Both analyses.-In all models presented below, we include two measures designed to control for the level of resources in the environment (McCarthy and Zald 1977), since RMT argues that SMO processes are highly dependent on the availability of resources that can be channeled into the movement. First, we include a yearly measure of the personal disposable income in New York State (logged), to control for the amount of discretionary monetary resources that individuals have to contribute to a SMO. Second, we include a yearly measure of the business failure rate, to control for upswings and downswings in the New York economy; this measure is the number of business failures in New York (logged). ${ }^{26}$

In addition to these two resource measures, we include a measure of how repressive the police were in a particular year with respect to a particular industry, to control for the possibility that state response to protesters may affect both tactical and goal innovation (McAdam 1983) and organizational survival (Zald and McCarthy 1980). To control for this, we include the percentage of all events in New York in a given year in each SMI that were met with police response. Data on police response were drawn directly from the newspaper reports of protest events, as described above. ${ }^{27}$

Finally, in all models included in the two tables below, we include

${ }^{26}$ An ideal measure of resources available to protest organizations would be the amount of foundation and elite philanthropic funding to these organizations (Jenkins and Eckert 1986; Jenkins 1998; McCarthy 2004). Unfortunately, such data do not exist for the organizations in our study over this time period. But, as a robustness check, we examined the correlations of our measures with yearly national-level figures for funding to the three movements in our study in the period 1960-80 (data provided by Craig Jenkins). Our measures were highly correlated with Jenkins's measures for the years these data were available.

${ }^{27}$ In this, we follow the lead of many scholars of protest policing who rely on data from newspapers (for some examples and reviews, see contributions in Della Porta and Reiter [1998]). Nonetheless, it should be noted that news accounts of police behavior may be biased (Earl et al. 2004). 


\section{Social Movement Industries}

dummy variables for two of the three SMIs (peace and women's) and dummy variables for two of the three decades in our analysis (the 1960s and 1970s), to account for unmeasured temporal and industrial heterogeneity (i.e., for omitted variable bias). Note that in models not shown, we experimented with a variety of other measures designed to get at the political opportunity structure (POS): \% Democrats in Congress, \%women in Congress, Democratic president, number of "call-ups" to military service, conservative coalition victories in House and Senate, \%federal budget spent on environment, and \%federal budget spent on military. None of these variables was significant in the models we ran, so we do not include them in models presented below, but we do address this lack of significance in our discussion and conclusion.

\section{Estimation Techniques}

Organizational tactical and goal specialization.-Because our data are arrayed as organization-years in a cross-sectional, time-series format, and there was evidence of first-order autocorrelation, ordinary least squares regression was inappropriate for our purposes. Therefore, we used generalized least squares (GLS) regression to estimate the effects of industrylevel factors on the two dependent variables (tactical and goal specialization). The GLS model, in its most simple form, is represented as

$$
Y_{t}=a+b X_{t}+e_{t},
$$

where $Y_{t}$ is the outcome on interest measured at time $t, X_{t}$ is the explanatory variable measured at time $t, e_{t}$ is the random error term, and $a$ and $b$ are unknown parameters (Ostrom 1990, p. 14). Models presented below were estimated using the $x t g l s$ command in Stata (version 8), which uses feasibility GLS to estimate cross-sectional time-series models.

A common problem in this type of data structure is autocorrelation: yearly observations for the same SMO will tend to be correlated. Xtgls allows a number of different choices for the working correlation matrix, and we experimented with all of these. We found that the models fit best when we specified first-order serial autocorrelation (ar1).

Organizational survival.-The dependent variable in our analysis of organizational survival is a yearly, dichotomous variable, coded 1 for the year after an organization's last protest. We used logistic regression to perform an event-history analysis of organizational persistence. This model is nonlinear and is expressed as

$$
P=\frac{\exp \left(x_{j} \beta\right)}{1+\exp \left(x_{j} \beta\right)},
$$




\section{American Journal of Sociology}

where $P$ is the probability of survival, $x$ is the set of covariates, and $\beta$ is the set of coefficients (including the constant). However, since our data are panel data, we used the $x$ tlogit command in Stata (ver. 8) and obtained random-effects estimates. Using random-effects estimation is an appropriate way to account for unmeasured heterogeneity in panel data for which one or more variables are temporally invariant, as is the case with the industry dummy variables.

\section{RESULTS}

Organizational Tactical and Goal Specialization

Table 1 presents the results of models predicting the level of specialization by an SMO in one of our three industries. Models 1 and 3 include only our control variables, and models 2 and 4 include our controls plus our measures designed to tap RMT and RPT. Models 2 and 4 show that as density in the SMI increases, organizational levels of tactical and goal specialization also increase. That is, consistent with McCarthy and Zald's (1977) hypotheses, industry-level competition increases the narrowness of tactics and goals adopted by SMOs. These models also include the quadratic term for industry density, and the coefficient (in both models) is negative. $^{28}$

Models 2 and 4 also test for the effects of industry concentration on organizations' levels of tactical and goal specialization. In both models, as the protest share of a particular organization increases, its level of specialization decreases, as we expected. Recall that this measure reflects how active a particular organization is in the industry in a particular year; these findings thus indicate that more active organizations are less likely to specialize. We argued above that such organizations are likely the more established ones. Therefore, this finding indicates that the more established an organization is, the less likely it is to specialize with respect to its tactics and goals. In a related finding, the incumbency measure (as expected, and consistent with the effect of the protest share measure) is also negative and significant. These findings follow the expectation of RPT that larger, established organizations are more likely to become generalists, because their size allows them to perform more operations for a lower cost than similarly motivated but less established organizations.

The last measure included in models 2 and 4 in table 1 is the statistical interaction term for incumbency and concentration. As expected, the effect

\footnotetext{
${ }^{28}$ In models not shown, we ran all models presented in table 1 by industry. These models produced very similar results, indicating that the effects we report in table 1 hold up within each industry as well as across all industries.
} 
TABLE 1

GLS Regression Models: Levels of Tactical and Goal Specialization of SMOs in the Peace, Women's, and Environmental Movements in New YoRk State, 1960-86

\begin{tabular}{|c|c|c|c|c|}
\hline & \multicolumn{2}{|c|}{$\begin{array}{c}\text { TaCtical } \\
\text { SpeCialization }\end{array}$} & \multicolumn{2}{|c|}{ Goal Specialization } \\
\hline & Model 1 & Model 2 & Model 3 & Model 4 \\
\hline$\ldots \ldots \ldots \ldots \ldots \ldots \ldots$ & $\begin{array}{l}-.16 \\
(.92)\end{array}$ & $\begin{array}{c}-.74 \\
(.62)\end{array}$ & $\begin{array}{r}-.78 \\
(.67)\end{array}$ & $\begin{array}{r}-1.53 \\
(.48)\end{array}$ \\
\hline Controls: & & & & \\
\hline $\begin{array}{l}\text { Personal disposable income } \\
\quad(\log ) \ldots \ldots \ldots \ldots \ldots \ldots \ldots \ldots\end{array}$ & $\begin{array}{l}.01 \\
(.04)\end{array}$ & $\begin{array}{l}.04 \\
(.03)\end{array}$ & $\begin{array}{l}.04 \\
(.03)\end{array}$ & $\begin{array}{l}.08 \\
(.05)\end{array}$ \\
\hline Business failure rate $(\log ) \ldots$ & $\begin{array}{l}-.07 * * \\
(.02)\end{array}$ & $\begin{aligned}-.03 * \\
(.01)\end{aligned}$ & $\begin{array}{r}-.03 * \\
(.01)\end{array}$ & $\begin{array}{l}-.04 * * * \\
(.01)\end{array}$ \\
\hline Police repression & $\begin{array}{l}.001 \\
(.001)\end{array}$ & $\begin{array}{l}.0002 \\
(.001)\end{array}$ & $\begin{array}{c}.0002 \\
(.0008)\end{array}$ & $\begin{array}{c}.0009 \\
(.0007)\end{array}$ \\
\hline Peace industry (dummy) .... & $\begin{array}{l}.08 \\
(.11)\end{array}$ & $\begin{array}{l}.02 \\
(.01)\end{array}$ & $\begin{array}{l}.05 \\
(.09)\end{array}$ & $\begin{array}{l}.01 \\
(.01)\end{array}$ \\
\hline $\begin{array}{l}\text { Women's industry } \\
\quad \text { (dummy) } \ldots \ldots \ldots \ldots \ldots . . . . . . . .\end{array}$ & $\begin{array}{l}.02 \\
(.02)\end{array}$ & $\begin{array}{l}.005 \\
(.01)\end{array}$ & $\begin{array}{l}.03 \\
(.02)\end{array}$ & $\begin{array}{l}.007 \\
(.01)\end{array}$ \\
\hline $1960 \mathrm{~s} \ldots \ldots \ldots \ldots \ldots \ldots \ldots \ldots$ & $\begin{array}{l}.001 \\
(.05)\end{array}$ & $\begin{array}{l}.03 \\
(.03)\end{array}$ & $\begin{array}{l}.003 \\
(.03)\end{array}$ & $\begin{array}{l}.03 \\
(.02)\end{array}$ \\
\hline 1970 s $\ldots \ldots \ldots \ldots \ldots \ldots \ldots \ldots$ & $\begin{array}{l}.06 \\
(.04)\end{array}$ & $\begin{array}{l}.05 \\
(.04)\end{array}$ & $\begin{array}{l}.06 \\
(.12)\end{array}$ & $\begin{array}{l}.05 \\
(.07)\end{array}$ \\
\hline Density .................... & & $\begin{array}{l}.005 * * * \\
(.001)\end{array}$ & & $\begin{array}{l}.007 * * * \\
(.001)\end{array}$ \\
\hline Density $^{2} \ldots \ldots \ldots$ & & $\begin{array}{l}-.00006 * * * \\
(.00001)\end{array}$ & & $\begin{array}{l}-.00005 * * * \\
(.00001)\end{array}$ \\
\hline Protest share & & $\begin{array}{l}-2.63 * * * \\
(.13)\end{array}$ & & $\begin{array}{l}-1.66 * * * \\
(.09)\end{array}$ \\
\hline Incumbent & & $\begin{array}{l}-.18 * * * \\
(.02)\end{array}$ & & $\begin{array}{l}-.14 * * * \\
(.01)\end{array}$ \\
\hline Industry concentration $\ldots \ldots$ & & $\begin{array}{l}.00009 * * * \\
(.00001)\end{array}$ & & $\begin{array}{l}.00005^{* * *} \\
(8.66 \mathrm{E}-6)\end{array}$ \\
\hline $\begin{array}{l}\text { Industry concentration } \times \\
\quad \text { incumbent } \ldots \ldots \ldots \ldots \ldots \ldots\end{array}$ & & $\begin{array}{l}-.0002 * * * \\
(.00003)\end{array}$ & & $\begin{array}{c}-.0001^{* * *} \\
(.00002)\end{array}$ \\
\hline Log likelihood & -75.63 & -565.46 & -412.83 & -962.37 \\
\hline
\end{tabular}


American Journal of Sociology

of this measure is negative and significant, indicating that the negative effect of incumbency on specialization is amplified when industry concentration is high. That is, more established (incumbent) organizations in an industry are, in general, less likely to specialize, and this is especially true when the SMI is more highly concentrated. This finding is consistent with RPT, which argues that in highly concentrated industries, it is the newer and less established organizations that specialize-not the incumbents.

Finally, with respect to the control variables, across all models an increase in the logged number of business failures decreases the level of specialization. This finding indicates that when resources are prevalent, there is likely to be more specialization of both tactics and goals. These findings run counter to what we expected on the basis of RMT, which argues that when resources are more plentiful, organizations are more likely to be generalists, relying on a variety of different tactics and expanding their goals to include more people. Instead, we find that when economic conditions are better, organizations are more likely to specialize.

One explanation for this unexpected finding is that generalist organizations, because of their economies of scale, can operate more cost-effectively during times of general economic hardship than can smaller specialists. During recessions, for example, when activists and donors have fewer resources to spread around, specialist SMOs are at a particular disadvantage. As mentioned in our discussion of theory above, the primary advantage that specialists have over generalists is not effectiveness or tactical competence; rather, it is their appeal to a particular movement identity. But supporter identity may be more or less tractable depending on the scarcity of expendable resources.

Activists and donors may simply be more discriminating about their resource use during economic downturns, choosing to support generalist organizations that have proven track records and that may spread their influence and activities more broadly. Conversely, during economic prosperity, donors may be more likely to give to specialized movement organizations, as suggested by the unanticipated positive relationship between resources and organizational specialization that we report in table 1. During economic contraction, specialists, which are typically smaller and unable to quickly adapt to changing economic conditions, may be more likely to lose out in the competition for scarce mobilizing resources. Specialist organizations, then, are most likely to abound during times of plenty, while generalists are better suited for times of scarcity. We are able to test this argument in the following analysis. As discussed below, our findings support this interpretation of the mechanism behind the counterintuitive finding that abundant resources increase SMO specialization. 


\section{Social Movement Industries}

\section{Organizational Survival}

Table 2 shows that none of the control variables significantly alters the persistence or survival of protest organizations. Across all four models in table 2, we find the expected nonlinear effect of density on the persistence of protest organizations, indicating that legitimacy of an SMI improves persistence in protest. However, as the negative sign on the squared term indicates, at very high levels of density the protective effect of legitimacy wanes and competitive pressures kick in.

In model 1 of table 2, we show the effect of tactical specialization on organizations' survival chances. As expected, the findings reveal that tactical specialists are more likely to cease protesting: the coefficient is positive and significant. However, when we include our interaction of organizational specialization with SMI concentration (HHI), we see that specialist SMOs in highly concentrated industries are more likely to persist (as predicted by RPT).

In model 2, we show that SMOs with highly specialized goals are also more likely to drop out of the protest pool, as indicated by the positive and significant coefficient on the failure rate. However, as was the case with tactical specialization, the persistence rate of organizations with specialized goals increases in more highly concentrated industries (as indicated by the negative effect of the interaction term on organizational failure). ${ }^{29}$ Thus, SMI concentration not only affects specialization levels of protest organizations, as shown in table 1 above, but it also conditions the probability that these specialist organizations will continue to exist as protesting organizations.

Specifically, what our two interaction terms (in combination with the coefficients on the main effects of tactical and goal specialization) show is that the baseline failure rate of specialists is higher than it is for generalists, but SMI concentration increases the survival rate of specialists. That is, the survival rate of specialists is higher for those in concentrated industries than it is for those in less-concentrated industries.

In addition to testing the RPT hypotheses about SMO survival, we decided to further investigate the implications of the findings reported in table 1. Recall that, contrary to what we expected on the basis of RMT, we found that resource scarcity in the general environment led to lower levels of organization-level specialization. We suspect that this finding reflects the economies of scale that enable large, generalist organizations to operate more cost-effectively during economic downturns. Therefore, generalist organizations should have better levels of fitness during times

${ }^{29}$ As we did for the models presented in table 1, we ran these analyses by industry to ensure that there are no differences between industries. The results were similar in each industry, confirming our expectations. 


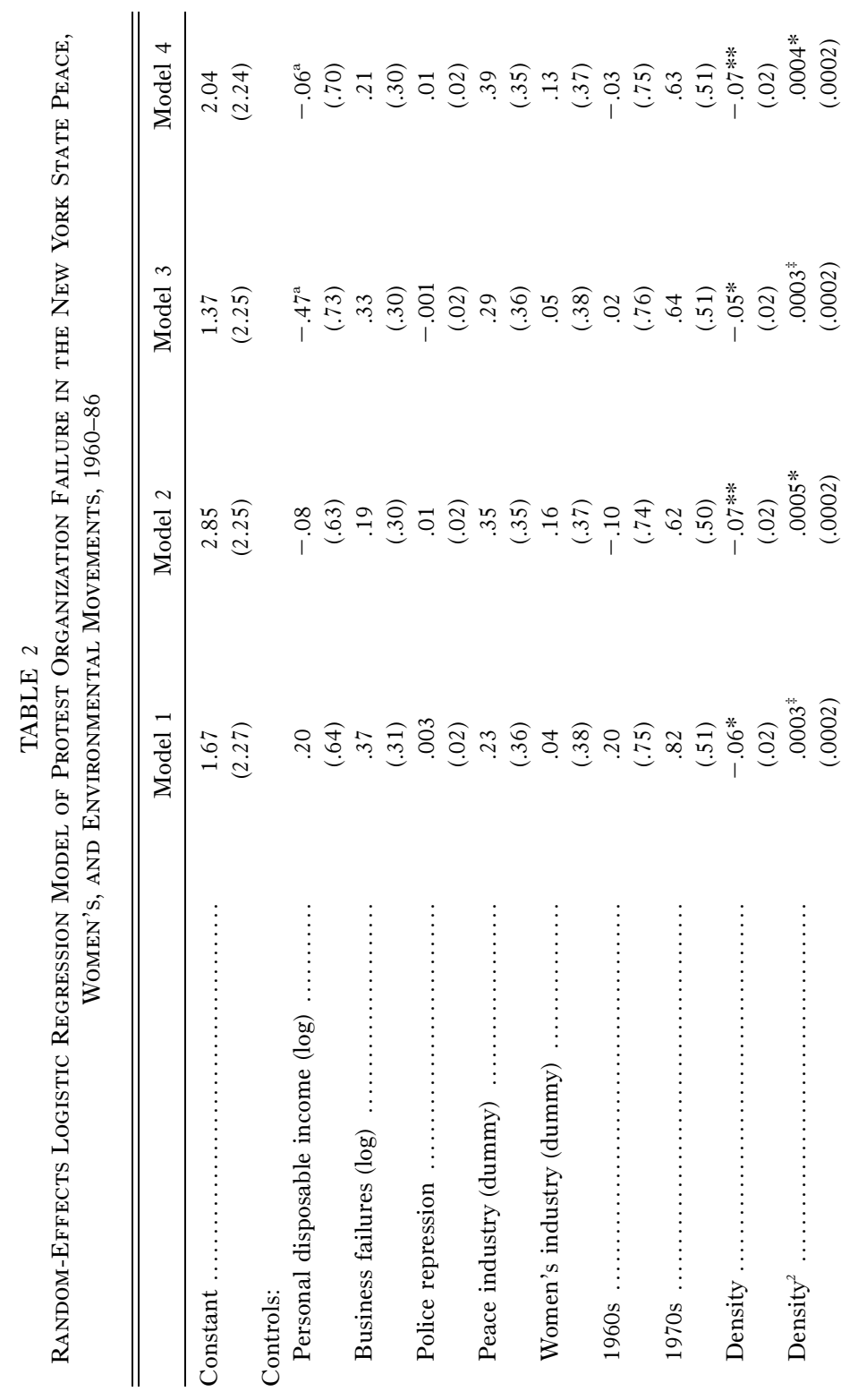




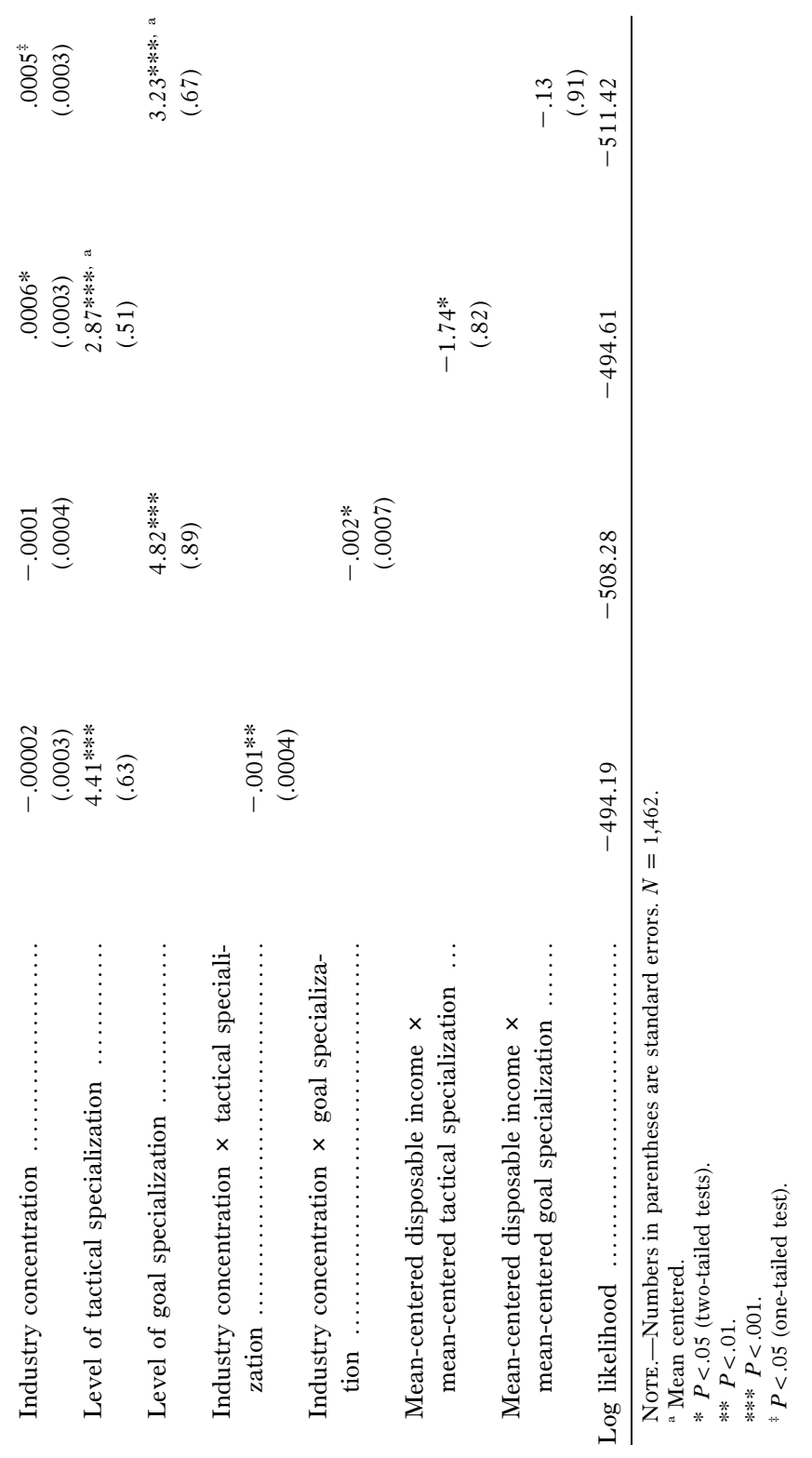




\section{American Journal of Sociology}

of resource scarcity, and specialist organizations should have lower rates of persistence when general resource levels are low.

We test this idea by including in models 3 and 4 of table 2 a statistical interaction between disposable income and specialization of the protest organization. In order to reduce collinearity, a common problem when including statistical interactions (Jaccard, Turrisi, and Wan 1990), we centered the two variables on their mean and created a product of the centered variables to assess the interaction effect (as suggested by Jaccard et al. [1990]). In model 3, we show that the product of disposable income and tactical specialization is negative and statistically significant at the .05 level. The negative interaction indicates that as disposable income increases, the main effect of tactical specialization on failure decreases. This finding supports the explanation that specialist organizations appear to be better suited for survival in an environment where resources are plentiful. This generalization, however, only applies to tactical specialization. In model 4, we see that the interaction effect of disposable income and goal specialization is smaller and is not statistically significant. Therefore, it appears that if cost advantages in economically turbulent environments go to generalist SMOs, this is only the case when the SMOs choose to diversify their tactics. SMOs that have a diverse body of goals do not appear to similarly advantaged.

\section{DISCUSSION AND CONCLUSIONS}

We began this article by noting that SMIs are rarely unified affairs. Instead, they are typically characterized by many different organizations pursuing related but subtly different goals and drawing on different sets of tactics. Building on insights from RMT and RPT, we argued for explicit attention to how industry-level characteristics of density and concentration affect organization-level specialization and how this, in turn, impacts persistence as a protest organization. ${ }^{30}$

There are several key findings commensurate with what RMT and RPT would predict. First, interorganizational competition increases the level of specialization of protest organizations. Second, more established protest organizations are more likely to adopt generalist tactics and espouse more general goals. Third, while industry concentration tends to lead protest organizations to specialize, more established organizations are less likely to specialize under such circumstances. Fourth, while gen-

\footnotetext{
${ }^{30}$ Our analysis shows that tactical choices and decisions about what claims to articulate are not made in a vacuum and instead are subject to the broader context, including other organizations (on a related point, see Downey and Rohlinger [2008]).
} 


\section{Social Movement Industries}

eralist organizations are more likely than specialists to survive, SMI concentration increases the survival rate of specialists.

Contrary to what RMT predicts, we found that when resources (i.e., disposable income) are low, protest organizations are less likely to specialize. We suggested that the reason for this is that generalist organizations actually have a cost advantage because they are larger and have organizational structures set up for dealing with a variety of environmental contingencies. Thus, in resource-scarce environments, generalists have a survival advantage over specialists. This supposition was confirmed in the analyses that showed that specialist SMOs are more likely to cease protesting when resources are scarce.

This research makes several contributions to the study of social movements. First, in part because of the use of case studies of individual movements or movement organizations, macro-organizational analysis of social movements "remains relatively underdeveloped" (Minkoff 2002, p. 260). In shifting the level of analysis from the individual movement or movement organization to the SMI, our analysis allows for a deeper understanding of the effects of interorganizational dynamics on organizational processes. This helps to answer a call by McAdam and Scott (2005) for researchers to pay more attention to organizational environments and interorganizational dynamics. That is, by testing hypotheses developed at the interorganizational level that are sensitive to the organizational environment, we are able to assess how SMI-level dynamics influence two important organizational outcomes: tactical and goal specialization and organizational survival. This approach, combined with our decision to examine these processes across three different SMIs (which gives us confidence that our results are likely not an artifact of a particular social movement), allows our findings to contribute to the development of theory at the intersection of social movement and organizational studies (e.g., McAdam and Scott 2005).

Second, this research is an important empirical contribution to the study of the influence of resource availability and competition on SMO structuration. Despite the centrality of resource competition in the original formulation of RMT by McCarthy and Zald (1977), few scholars have examined its implications thoroughly. Competition, while an important dynamic of most organizational research, has largely been left out of analyses of protest organizations.

Third, we enrich RMT by drawing on RPT, but the benefits of this synthesis are not simply unidirectional. Our findings suggest that RPT is able to offer a more nuanced understanding of the dynamics of organizational specialization when combined with RMT. While RPT looks exclusively at the dynamics of intra-industry competition, we expand our analysis to also include the effects of general resource scarcity, per RMT. 
American Journal of Sociology

In so doing, we find that generalist organizations have survival advantages in resource-scarce environments. This finding suggests that social movement and organizational scholars should consider the influence of the broader environmental resource base (in addition to niche-specific resources) on specialization.

Had we focused solely on RMT (as most social movement scholars have), we would have concluded that interorganizational competition (measured by density) leads organizations to specialize, but that this strategy contributes to organizational failure. By adding RPT, we can qualify these findings by saying that SMI concentration (rather than density) creates the conditions under which specialist organizations may survive and flourish. Thus, our analysis leads to a more nuanced view of the effects of specialization on survival. In some instances, specialization may be a liability to survival, while under other environmental conditions it enhances survival.

One might reasonably ask how our findings on tactical specialization compare on a substantive level with past research on tactical innovation (McAdam 1983; McCammon 2003). We think that there are two primary differences. First, past research on tactical innovation has been chiefly concerned with explaining how specific organizations innovate with respect to specific tactical choices when faced with external constraints (e.g., state repression, countermovements, etc.) and how innovating can increase organizations' chances of viability. Rather than focusing on specific tactics, we evaluate the more general strategy of specializing. In other words, we are concerned with an organization's repertoire size (relative to the repertoire size of other organizations in the same industry). Second, while past research (e.g., McAdam 1983) has focused on how external factors affect organizations, we expand on this by examining how interorganizational competition and industry competition affect organizational outcomes. It is interesting to consider that if we were to combine insights from this past research with our own findings, we might conclude that tactical innovation can lead to organizational survival, but it is best not to drop tactics used in the past, since, according to our findings, generalists have survival advantages.

In addition, our findings have more general implications regarding the long-term viability of SMIs. The interorganizational dynamics of competition observed here, while sometimes decreasing the survival chances of any single SMO, may actually enhance the survivability of the industry. The findings suggest that specialists and generalists are interdependent and together create a lively protest industry addressing a wide variety of goals and tactics, bringing in participants and donors who might be ignored under a more centralized system of authority. Unlike other studies of innovation, then, which suggest that individual SMOs adapt to success 
and failures or external threats from their environment, our findings indicate that the SMI also adapts as some SMOs fail to survive and resources are reshuffled between specialists and generalists.

We conclude with some suggestions for future research. First, we call on other researchers to devise alternative and creative ways to operationally define the SMI. As noted above, scholars have used directories of associations (sometimes in combination with surveys and interviews) and archival materials to define SMIs. We have added to this repertoire of data sources by using accounts of protest events. We have followed Everett (1992) in defining the SMI as comprising all organizations that take part in public protest events associated with the industry. In doing so, we have defined inclusion in the SMI based on what organizations do. However, there are likely many other ways to define the SMI, and we call for researchers to think seriously about how this may be done in order to ascertain whether our findings regarding the importance of industry-level dynamics hold when the SMI is defined differently. One potentially useful method would be to ask questions about the organizations to which individuals belong on a nationally representative survey (e.g., the GSS). By using hypernetwork techniques (McPherson 1982; Chaves et al. 1999), one could create a nationally representative sample of organizations associated with a particular SMI or the entire SMS.

Second, we call for research that considers additional types of organizational outcomes (beyond tactical and goal specialization) and examines how industry-level dynamics impact such outcomes. For example, scholars could examine how industry competition and concentration impact levels of protest. Future research should consider how industry-level dynamics (net of and in combination with resources) impact other kinds of organizational outcomes as well.

Third, a fruitful area of inquiry will be to examine how ecological dynamics affect social movement frames. Benford (1993) examines how competition and conflicts over frames can arise within an SMI (he terms these "frame disputes"). It would be interesting to examine how ecological dynamics affect framing processes; for example, how does competition affect the level of specialization of a particular frame articulated by a movement organization? Examining specialization of frames is important, since frame specialization has been linked to successful outcomes for SMOs (Cress and Snow 2000).

Fourth, in our models we included a number of measures designed to tap dimensions of the POS, suggesting that these dimensions might have an independent effect on organizational specialization and/or persistence. As we noted above, none of the coefficients on these measures were significant, casting doubt on the idea that the POS impacts either organizational specialization or persistence in our three SMIs. This may not be 


\section{American Journal of Sociology}

especially surprising, since the literature on the POS does not claim that the dimensions of the POS should necessarily affect organizational specialization or persistence. However, the POS is a compelling concept and one that has proven to be quite useful in explaining the emergence and outcomes of social movements. Thus, we would encourage future researchers to attend to this concept when examining organizational dynamics, if for no other reason than to improve on our lack of findings in this study.

Fifth, we chose to examine the three SMIs that we did because all three were subject to industry-level analyses in the past, and we were interested in seeing how previous findings resonated with our own. But it is important now to extend these analyses to other SMIs to see if the dynamics we uncovered are at work in other industries, in other countries, and in other eras. Certainly, past research hints that these are more general processes that likely transcend space and time (e.g., Della Porta and Tarrow 1986).

Finally, we conclude with a very broad call for more research on the nexus of social movements and organizational theories. Here, we have attempted to bring organizational theories to bear on social movement processes and have shown these theories to add to what we know about the factors affecting tactical and goal specialization. However, future research should also consider ways in which social movement theories can help explain organizational phenomena. Research that crosses the boundaries between these two subdisciplines promises to teach us a great deal about both movements and organizations (McAdam and Scott 2005).

\section{APPENDIX A}

Tactics Used by Social Movement Organizations at Protest Events in the U.S. Peace, Women's, and Environmental Movements, 1960-1986

\section{Attack/conflict/clash}

Boycott (organized refusal to buy or use a product or service)

Ceremony (celebration or protest of status transition, such as birth or death, etc.)

Civil disobedience

Dramaturgical demonstration (concerts, theatrical presentation, performing arts)

Information distribution (tabling, petition gathering, teach-ins)

Lawsuit/legal maneuver by social movement organization or group 


\section{Social Movement Industries}

March (protesters move from one location to another; distinguished from walking in a circle)

Motorcade

Movement organization formation announcement

Picket (walking in circle with picket signs)

Press conference/statement

Rally/demonstration

Riot/melee/mob violence

Symbolic display (menorah, crèche, cross burning, graffiti, standing displays)

Vigil (including silent witness and meditation)

Wildcat strike/slowdown/sick-in

\section{APPENDIX B}

Goals Articulated by Social Movement Organizations at Protest Events in the U.S. Peace, Women's, and Environmental Movements, 1960-1986

\section{Peace Movement}

Disarmament in general

Opposing atomic testing

Opposing atomic weapons (construction, purchase, distribution, storage)

Opposing biological/chemical weapons (construction, purchase, distribution, storage)

Opposing conventional weapons (construction, purchase, distribution, storage)

Opposing military infrastructure

Opposing military maneuvers

Opposing ROTC, military, CIA recruitment on campus

Opposing the draft

Opposing the export of conventional weapons 
American Journal of Sociology

Opposing the Gulf War

Opposing the Korean War

Opposing the Vietnam War

Opposing the war in Afghanistan

Opposing the war in Yugoslavia

Opposing U.S. involvement in Central America

Opposing U.S. involvement in non-U.S. wars

Opposing U.S. military involvement in Cuba

Peace, pacifism in general

Supporting retrieving or recovering POW/MIAs

Women's Movement

Ending discrimination in employment

Ending violence against women

Equality in education

Equal pay/comparable worth

Equal Rights Amendment (ERA)

Federal/state funding for women's initiatives (shelters, clinics, etc.)

Gender quotas/affirmative action

More positive media depictions, more depictions, fewer negative depictions

Women's civil rights, general

Environmental Movement

Air quality protection

Environmental protection in general

Landscape protection (plants, trees)

Limiting waste/recycling

Opposing the current method of solid waste disposal

Ozone protection to prevent global warming 
Social Movement Industries

Rainforest preservation

Reducing noise pollution

Restriction of pharmaceuticals/chemicals

Soil protection

Water quality protection

Zero population growth, as environmental issue

\section{APPENDIX C}

Examples of Dependent Variables for Three Protest Organizations

Peace SMI.-The American Friends Service Committee (AFSC) participated in 36 different protest events in New York associated with the peace movement (but was not reported at events in New York associated with the women's or environmental movements during this time period). The first of these events took place in 1960 and the last in 1982; thus, we infer that this group persisted as a peace protest organization from 1960 through 1982. Table C1 shows the AFSC's levels of tactical and goal specialization in each of the years in which it protested.

Environmental SMI.-The Sierra Club participated in 39 different protest events in New York associated with the environmental movement (but was not reported at events in New York associated with the women's or peace movements during this time). The first of these events took place in 1966 and the last in 1986; thus, we infer that this group persisted as an environmental protest organization from 1966 through 1986. Table C2 shows the Sierra Club's levels of tactical and goal specialization in each of the years in which it protested.

Women's SMI.-The Women's Equity Action League (WEAL) participated in five events in New York associated with the women's movement (but was not reported at events in New York associated with the environmental or peace movements during this time period). The first of these events took place in 1974 and the last in 1986; thus, we infer that this group persisted as a women's protest organization from 1974 through 1986. Table C3 shows WEAL's levels of tactical and goal specialization in each of the years in which it protested. 
TABLE C1

Protest Activity and Specialization, AFSC

\begin{tabular}{cccc}
\hline \hline Year & $\begin{array}{c}\text { No. of } \\
\text { Events }\end{array}$ & $\begin{array}{c}\text { Tactical } \\
\text { Specialization }\end{array}$ & $\begin{array}{c}\text { Goal } \\
\text { Specialization }\end{array}$ \\
\hline $1960 \ldots \ldots$ & 2 & -.60 & -.33 \\
$1961 \ldots \ldots$ & 3 & -.75 & -1.00 \\
$1962 \ldots \ldots$ & 5 & -.55 & -.36 \\
$1963 \ldots \ldots$ & 1 & -.14 & -.13 \\
$1964 \ldots \ldots$ & 0 & & \\
$1965 \ldots \ldots$ & 3 & -.25 & -.27 \\
$1966 \ldots \ldots$ & 6 & -.64 & -.56 \\
$1967 \ldots \ldots$ & 2 & -.18 & -.17 \\
$1968 \ldots \ldots$ & 0 & & \\
$1969 \ldots \ldots$ & 2 & -.21 & -.09 \\
$1970 \ldots \ldots$ & 2 & -.25 & -.12 \\
$1971 \ldots \ldots$ & 1 & -.06 & -.06 \\
$1972 \ldots \ldots$ & 1 & -.14 & -.05 \\
$1973 \ldots \ldots$ & 1 & -.09 & -.14 \\
$1974 \ldots \ldots$ & 0 & & \\
$1975 \ldots \ldots$ & 0 & & \\
$1976 \ldots \ldots$ & 0 & & \\
$1977 \ldots \ldots$ & 1 & -.16 & -.11 \\
$1978 \ldots \ldots$ & 1 & -.16 & -.16 \\
$1979 \ldots \ldots$ & 1 & -.11 & -.08 \\
$1980 \ldots \ldots$ & 1 & -.22 & -.09 \\
$1981 \ldots \ldots$ & 2 & -.43 & -.18 \\
$1982 \ldots \ldots$ & 1 & -.11 & -.43 \\
\hline
\end{tabular}

TABLE C2

Protest Activity and Specialization, Sierra

Club

\begin{tabular}{cccc}
\hline \hline Year & $\begin{array}{c}\text { No. of } \\
\text { Events }\end{array}$ & $\begin{array}{c}\text { Tactical } \\
\text { Specialization }\end{array}$ & $\begin{array}{c}\text { Goal } \\
\text { Specialization }\end{array}$ \\
\hline $1960 \ldots \ldots$ & 0 & & \\
$1961 \ldots \ldots$ & 0 & & \\
$1962 \ldots \ldots$ & 0 & & \\
$1963 \ldots \ldots$ & 0 & & \\
$1964 \ldots \ldots$ & 0 & & \\
$1965 \ldots \ldots$ & 0 & & \\
$1966 \ldots \ldots$ & 1 & -.25 & -.50 \\
$1967 \ldots \ldots$ & 1 & -.20 & -.25 \\
$1968 \ldots \ldots$ & 0 & & \\
$1969 \ldots \ldots$ & 4 & -.67 & -1.00 \\
$1970 \ldots \ldots$ & 3 & -.43 & -.38 \\
$1971 \ldots \ldots$ & 4 & -.11 & -.07 \\
$1972 \ldots \ldots$ & 1 & -.14 & -.06
\end{tabular}


TABLE C2 (Continued)

\begin{tabular}{|c|c|c|c|}
\hline Year & $\begin{array}{l}\text { No. of } \\
\text { Events }\end{array}$ & $\begin{array}{c}\text { Tactical } \\
\text { Specialization }\end{array}$ & $\begin{array}{c}\text { Goal } \\
\text { Specialization }\end{array}$ \\
\hline $1973 \ldots \ldots$ & 1 & -.50 & -.13 \\
\hline $1974 \ldots \ldots$ & 2 & -.40 & -.13 \\
\hline $1975 \ldots \ldots$ & 1 & -.14 & -.20 \\
\hline $1976 \ldots \ldots$ & 0 & & \\
\hline $1977 \ldots \ldots$ & 3 & -.33 & -.23 \\
\hline $1978 \ldots \ldots$ & 3 & -.60 & -.30 \\
\hline $1979 \ldots \ldots$ & 0 & & \\
\hline $1980 \ldots \ldots$ & 4 & -1.00 & -.71 \\
\hline $1981 \ldots \ldots$ & 4 & -.80 & -.40 \\
\hline $1982 \ldots \ldots$ & 3 & -.60 & -.40 \\
\hline $1983 \ldots \ldots$ & 3 & -.60 & -.27 \\
\hline $1984 \ldots \ldots$ & 0 & & \\
\hline $1985 \ldots \ldots$ & 0 & & \\
\hline $1986 \ldots \ldots$ & 1 & -.50 & -.40 \\
\hline
\end{tabular}

TABLE C3

Protest Activity and Specialization, WEAL

\begin{tabular}{|c|c|c|c|}
\hline Year & $\begin{array}{l}\text { No. of } \\
\text { Events }\end{array}$ & $\begin{array}{c}\text { Tactical } \\
\text { Specialization }\end{array}$ & $\begin{array}{c}\text { Goal } \\
\text { Specialization }\end{array}$ \\
\hline $1960 \ldots \ldots$ & 0 & & \\
\hline $1961 \ldots \ldots$ & 0 & & \\
\hline $1962 \ldots \ldots$ & 0 & & \\
\hline $1963 \ldots \ldots$ & 0 & & \\
\hline $1964 \ldots \ldots$ & 0 & & \\
\hline $1965 \ldots \ldots$ & 0 & & \\
\hline $1966 \ldots \ldots$ & 0 & & \\
\hline $1967 \ldots \ldots$ & 0 & & \\
\hline $1968 \ldots \ldots$ & 0 & & \\
\hline $1969 \ldots \ldots$ & 0 & & \\
\hline $1970 \ldots \ldots$ & 0 & & \\
\hline $1971 \ldots \ldots$ & 0 & & \\
\hline $1972 \ldots \ldots$ & 0 & & \\
\hline $1973 \ldots \ldots$ & 0 & & \\
\hline $1974 \ldots \ldots$ & 1 & -.25 & -.08 \\
\hline $1975 \ldots \ldots$ & 0 & & \\
\hline $1976 \ldots \ldots$ & 0 & & \\
\hline $1977 \ldots \ldots$ & 1 & -.11 & -.15 \\
\hline $1978 \ldots \ldots$ & 0 & & \\
\hline $1979 \ldots \ldots$ & 0 & & \\
\hline $1980 \ldots \ldots$ & 2 & -.14 & -.36 \\
\hline $1981 \ldots \ldots$ & 0 & & \\
\hline $1982 \ldots \ldots$ & 0 & & \\
\hline $1983 \ldots \ldots$ & 0 & & \\
\hline $1984 \ldots \ldots$ & 0 & & \\
\hline
\end{tabular}


American Journal of Sociology

\begin{tabular}{llll}
$1985 \ldots \ldots$ & 0 & & \\
$1986 \ldots \ldots$ & 1 & -.17 & -.10 \\
\hline
\end{tabular}

\section{REFERENCES}

Amenta, Edwin, Neal Caren, and Sheera Joy Olasky. 2005. "America's Most Publicized SMOs: A New Approach to Social Movements." Paper presented at the annual meeting of the American Sociological Association, Philadelphia, August.

Andrews, Andrew, and Bob Edwards. 2005. "The Organizational Structure of Local Environmentalism." Mobilization 10 (2): 213-34.

Barnett, William P., and Glenn R. Carroll. 1987. "Competition and Mutualism among Early Telephone Companies." Administrative Science Quarterly 30:400-421.

Bearman, Peter S., and Kevin D. Everett. 1993. "The Structure of Social Protest, 1961-1983.” Social Networks 15:171-200.

Benford, Robert D. 1993. "Frame Disputes within the Nuclear Disarmament Movement." Social Forces 71 (3): 677-701.

Benford, Robert D., and Louis A. Zurcher. 1990. "Instrumental and Symbolic Competition among Social Movement Organizations." Pp. 125-39 in Peace Action in the Eighties, edited by Sam Marullo and John Lofland. New Brunswick, N.J.: Rutgers University Press.

Brulle, Robert J. 2000. Agency, Democracy and Nature: The U.S. Environmental Movement from a Critical Theory Perspective. Cambridge, Mass.: MIT Press.

Carroll, Glenn R. 1985. "Concentration and Specialization: Dynamics of Niche Width." American Journal of Sociology 90:1262-83.

Carroll, Glenn R., and Michael T. Hannan. 2000. The Demography of Corporations and Industries. Princeton, N.J.: Princeton University Press.

Carroll, Glenn R., and Anand Swaminathan. 1992. "The Organizational Ecology of Strategic Groups in the American Brewing Industry from 1975 to 1990." Industrial and Corporate Change 1:65-97.

—. 2000. "Why the Microbrewery Movement? Organizational Dynamics of Resource Partitioning in the U.S. Brewing Industry." American Journal of Sociology 106:715-62.

Chaves, Mark, Mary Ellen Konieczny, Kraig Beyerlein, and Emily Barman. 1999. "The National Congregation Study: Background, Methods and Selected Results." Journal for the Scientific Study of Religion 38:458-76.

Cress, Daniel M., and David A. Snow. 2000. "The Outcomes of Homeless Mobilization: The Influence of Organization, Disruption, Political Mediation, and Framing." American Journal of Sociology 105 (4): 1063-1104.

Davenport, Christian, and Patrick Ball. 2002. "Exploring the Implications of Source Selection in the Case of Guatemalan State Terror." Journal of Conflict Resolution 46 (3): $427-50$.

Della Porta, Donatella, and Herbert Reiter. 1998. Policing Protest: The Control of Mass Demonstrations in Western Democracies. Minneapolis: University of Minnesota Press.

Della Porta, Donatella, and Sidney Tarrow. 1986. "Unwanted Children: Political Violence and the Cycle of Protest in Italy, 1966-1973." European Journal of Political Resarch 14 (5-6): 607-32.

Downey, Dennis J., and Deana A. Rohlinger. 2008. "Linking Strategic Choice with Macro-organizational Dynamics: Strategy and Social Movement Articulation." Research in Social Movements, Conflicts, and Change, in press.

Earl, Jennifer, Andrew Martin, John D. McCarthy, and Sarah A. Soule. 2004. "The 


\section{Social Movement Industries}

Use of Newspaper Data in the Study of Collective Action." Annual Review of Sociology 30:65-80.

Earl, Jennifer, and Sarah A. Soule. 2006. "Seeing Blue: Going Behind the Baton to Explain Policing at Public Protest Events." Mobilization 11 (2): 145-64.

Earl, Jennifer, Sarah A. Soule, and John D. McCarthy. 2003. "Protests under Fire? Explaining Protest Policing." American Sociological Review 69:581-606.

Edwards, Bob, and Michael W. Foley. 2003. "Social Movement Organizations beyond the Beltway: Understanding the Diversity of One Social Movement Industry." Mobilization 8 (1): 87-107.

Edwards, Bob, and Sam Marullo. 1995. "Organizational Mortality in a Declining Social Movement: The Demise of Peace Movement Organizations in the End of the Cold War Era." American Sociological Review 60 (6): 908-27.

Edwards, Bob, and John D. McCarthy. 1992. "Social Movement Schools." Sociological Forum 7 (3): 541-51.

- 2004. "Resources and Social Movement Mobilization." Pp. 116-52 in The Blackwell Companion to Social Movements, edited by David A. Snow, Sarah A. Soule, and Hanspeter Kriesi. London: Blackwell.

Everett, Kevin D. 1992. "Professionalization and Protest: Changes in the Social Movement Sector, 1961-1983." Social Forces 70 (4): 957-75.

Fernandez, Roberto M., and Doug McAdam. 1988. "Social Networks and Social Movements: Multiorganizational Fields and Recruitment to Mississippi Freedom Summer." Sociological Forum 3 (3): 357-82.

Freeman, John, and Pino G. Audia. 2006. "Community Ecology and the Sociology of Organizations." Annual Review of Sociology 32:145-69.

Freeman, John, and Alessandro Lomi. 1994. "Resource Partitioning and Foundings of Banking Cooperatives in Italy." Pp. 269-93 in Evolutionary Dynamics of Organizations, edited by Joel A. C. Baum and Jitendra V. Singh. New York: Oxford University Press.

Gamson, William. 1975. The Strategy of Social Protest. Belmont, Calif.: Wadsworth. . 1987. Introduction. Pp. 1-7 in Social Movements in an Organizational Society, by Mayer N. Zald and John D. McCarthy. New Brunswick, N.J.: Transaction Books.

Gerlach, Luther P., and Virginia H. Hine. 1970. People, Power, Change: Movements of Social Transformation. Indianapolis: Bobbs-Merrill.

Goldman, Peter. 1969. Report from Black America. New York: Simon \& Schuster.

Haider-Markel, Donald P. 1997. "Interest Group Survival: Shared Interests versus Competition for Resources." Journal of Politics 59 (3): 903-12.

Haines, Herbert. 1984. "Black Radicalization and the Funding of Civil Rights: 1957-1970." Social Problems 23 (1): 31-43.

Hannan, Michael T., and Glenn R. Carroll. 1992. Dynamics of Organizational Populations. New York: Oxford University Press.

Hannan, Michael T., and John Freeman. 1977. "The Population Ecology of Organizations." American Journal of Sociology 82:929-64. . 1989. Organizational Ecology. Cambridge, Mass.: Harvard University Press.

Jaccard, James, Robert Turrisi, and Choi K. Wan. 1990. Interaction Effects in Multiple Regression. Newbury Park, Calif.: Sage.

Jenkins, J. Craig. 1998. "Channeling Social Protest: Foundation Patronage of Contemporary Social Movements." Pp. 206-16 in Private Action and the Public Good, edited by Walter W. Powell and Elisabeth S. Clemens. New Haven, Conn.: Yale University Press.

Jenkins, J. Craig, and Craig M. Eckert. 1986. "Channeling Black Insurgency: Elite Patronage and Professional Social Movement Organizations in the Development of the Black Movement." American Sociological Review 51 (6): 812-29.

Kempton, Willett, Dorothy C. Holland, Katherine Bunting-Howarth, Erin Hannan, 


\section{American Journal of Sociology}

and Christopher Payne. 2001. "Local Environmental Groups: A Systematic Enumeration in Two Geographical Areas." Rural Sociology 66 (4): 557-78.

King, Brayden G, Keith G. Bentele, and Sarah A. Soule. 2007. "Congressional AgendaSetting and Fluctuating Attention to Civil and Political Rights, 1960-1987." Social Forces 86 (1): 137-63.

King, Brayden G, and Marie Cornwall. 2005. "Specialists and Generalists: Learning Strategies in the Woman Suffrage Movement, 1866-1918." Research in Social Movements, Conflicts, and Change 26:3-34.

King, Brayden G, and Sarah A. Soule. 2007. "Social Movements as Extra-institutional Entrepreneurs: The Effect of Protest on Stock Price Returns." Administrative Science Quarterly 52 (3): 413-42.

Koopmans, Ruud. 1993. "The Dynamics of Protest Waves: West Germany, 1965-1989." American Sociological Review 58:637-58.

Laumann, Edward O., and David Knoke. 1987. The Organizational State: Social Choice in National Policy Domains. Madison: University of Wisconsin Press.

McAdam, Doug. 1982. Political Process and the Development of Black Insurgency, 1930-1970. Chicago: University of Chicago Press.

. 1983. "Tactical Innovation and the Pace of Insurgency." American Sociological Review 48:735-54.

McAdam, Doug, and W. Richard Scott. 2005. "Organizations and Movements." Pp. 4-40 in Social Movements and Organization Theory, edited by Gerald F. Davis, Doug McAdam, W. Richard Scott, and Meyer N. Zald. New York: Cambridge University Press.

McAdam, Doug, and Yang Su. 2002. "The War at Home: Antiwar Protests and Congressional Voting, 1965-1973." American Sociological Review 67:696-721.

McCammon, Holly J. 2003. "Out of the Parlors and Into the Streets': The Changing Tactical Repertoire of the U.S. Women's Suffrage Movements." Social Forces 81: 787-818.

McCarthy, Deborah. 2004. "Environmental Justice Grantmaking: Elites and Activists Collaborate to Transform Philanthropy." Sociological Inquiry 74:250-73.

McCarthy, John D., Clark McPhail, and Jackie Smith. 1996. "Images of Protest: Dimensions of Selection Bias in Media Coverage of Washington Demonstrations, 1982-1992." American Sociological Review 61:478-99.

McCarthy, John D., Mark Wolfson, David P. Baker, and Elaine Mosakawski. 1988. "The Founding of Social Movement Organizations: Local Citizens' Groups Opposing Drunken Driving." Pp. 71-84 in Ecological Models of Organizations, edited by Glenn Carroll. Cambridge, Mass.: Ballinger.

McCarthy, John D., and Mayer N. Zald. 1977. "Resource Mobilization and Social Movements: A Partial Theory.” American Journal of Sociology 82:1212-41.

- 2001. "The Enduring Vitality of Resource Mobilization Theory of Social Movements." Pp. 533-65 in Handbook of Sociological Theory, edited by Jonathan H. Turner. New York: Kluwer Academic/Plenum.

McPherson, J. Miller. 1982. "Hypernetwork Sampling: Duality and Differentiation among Voluntary Associations." Social Networks 3:225-49.

Meyer, David S., and Douglas R. Imig. 1993. "Political Opportunity and the Rise and Decline of Interest Group Sectors." Social Science Journal 30 (3): 253-70.

Minkoff, Debra C. 1993. "The Organization of Survival: Women's and Racial-Ethnic Voluntarist and Activist Organizations, 1955-1985." Social Forces 71 (4): 887-908.

—. 1994. "From Service Provision to Institutional Advocacy: The Shifting Legitimacy of Organizational Forms." Social Forces 72 (4): 943-69.

- 1995. "Interorganizational Influences on the Founding of African American Organizations, 1955-1985." Sociological Forum 10 (1): 51-79.

. 1997. "The Sequencing of Social Movements." American Sociological Review 62:779-99. 


\section{Social Movement Industries}

1999. "Bending with the Wind: Strategic Change and Adaptation by Women's and Racial Minority Organizations." American Journal of Sociology 6:1666-1703.

. 2002. "Macro-organizational Analysis." Pp. 260-85 in Methods of Social Movement Research, edited by Bert Klandermans and Suzanne Staggenborg. Minneapolis: University of Minnesota Press.

Morris, Aldon D. 1984. The Origins of the Civil Rights Movement: Black Communities Organizing for Change. New York: Free Press.

Mueller, Carol. 1997. "Media Measurement Models of Protest Event Data." Mobilization 2 (2): 165-84.

Oliver, Pamela E., and Gregory Maney. 2000. "Political Processes and Local Newspaper Coverage of Protest Events: From Selection Bias to Triadic Interactions." American Journal of Sociology 106:463-505.

Oliver, Pamela E., and Daniel J. Myers. 1999. "How Events Enter the Public Sphere: Conflict, Location, and Sponsorship in Local Newspaper Coverage of Public Events." American Journal of Sociology 105:38-87.

Olson, Mancur. 1965. The Logic of Collective Action. Cambridge, Mass.: Harvard University Press.

Olzak, Susan, and Emily Ryo. 2007. "Organizational Diversity, Vitality, and Outcomes in the African American Civil Rights Movement." Social Forces 85:1561-92.

Olzak, Susan, and Noah Uhrig. 2001. "The Ecology of Tactical Overlap." American Sociological Review 66:694-717.

Ortiz, David G., Daniel J. Myers, N. Eugene Walls, and Maria-Elena D. Diaz. 2005. "Where Do We Stand with Newspaper Data?" Mobilization 10 (3): 397-419.

Ostrom, Charles. 1990. Time Series Analysis: Regression Techniques. Thousand Oaks, Calif.: Sage.

Rao, Hayagreeva. 1994. "The Social Construction of Reputation: Certification Contests, Legitimation, and the Survival of Organizations in the American Automobile Industry: 1895-1912." Strategic Management Journal 15:29-44.

Rosen, Sherwin. 1974. "Hedonic Prices and Implicit Markets: Product Differentiation in Pure Competition." Journal of Political Economy 82:34-55.

Rosenthal, Naomi, Meryl Fingrutd, Michel Ethier, Roberta Karant, and David McDonald. 1985. "Social Movements and Network Analysis: A Case Study of Nineteenth-Century Women's Reform in New York State." American Journal of Sociology 90 (5): 1022-54.

Ruef, Martin. 2000. "The Emergence of Organizational Forms: A Community Ecology Approach." American Journal of Sociology 106:658-714.

Singh, Jitendra, and Charles Lumsden. 1990. "Theory and Research in Organizational Ecology." Annual Review of Sociology 16:161-95.

Shaked, Avner, and John Sutton. 1982. "Relaxing Price Competition through Product Differentiation." Review of Economic Studies 49:3-13.

Smith, Jackie. 1997. "Characteristics of the Modern Transnational Social Movement Sector." Chap. 3 in Transnational Social Movements and Global Politics, edited by Jackie Smith, Charles Chafield, and Ronald Pagnucco. Syracuse, N.Y.: Syracuse University Press.

—. 2002. "Bridging Global Divides? Strategic Framing and Solidarity in Transnational Social Movement Organizations." International Sociology 17 (4): $505-28$.

- 2004. "Transnational Processes and Movements." Pp. 311-35 in The Blackwell Companion to Social Movements, edited by David A. Snow, Sarah A. Soule, and Hanspeter Kriesi. Malden, Mass.: Blackwell.

. 2005. "Building Bridges or Building Walls? Explaining Regionalization among Transnational Social Movement Organizations." Mobilization 10 (2): 251-70.

Soule, Sarah A., and Jennifer Earl. 2005. "A Movement Society Evaluated: Collective Protest in the United States, 1960-1986." Mobilization 10 (3): 345-64. 


\section{American Journal of Sociology}

Stryker, Sheldon. 2000. "Identity Competition: Key to Differential Social Movement Participation?" Pp. 21-40 in Self, Identity and Social Movements, edited by Sheldon Stryker, Timothy J. Owens, and Robert W. White. Minneapolis: University of Minnesota Press.

Swaminathan, Anand. 1993. The Evolution of Specialist Organizational Forms in Mature Industries: Beer Brewing and Wine Making in Post-Prohibition America. Ph.D. dissertation. University of California, Berkeley, Department of Business Administration.

- 2001. "Resource Partitioning and the Evolution of Specialist Organizations:

The Role of Location and Identity in the U.S. Wine Industry." Academy of Management Journal 44:1169-85.

Swank, Eric. 2000. "In Newspapers We Trust? Assessing the Credibility of News Sources That Cover Protest Campaigns." Research in Social Movements, Conflict, and Change 22:27-52.

Tarrow, Sidney. 2001. "Transnational Politics: Contention and Institutions in International Politics." Annual Review of Political Science 4:1-20.

Taylor, Verta. 1989. "Social Movement Continuity." American Sociological Review 54: $761-75$.

Tilly, Charles. 2004. Social Movements, 1768-2004. Boulder, Colo.: Paradigm.

Van Dyke, Nella, Sarah A. Soule, Verta Taylor. 2004. "The Targets of Social Movements: Beyond a Focus on the State." Research in Social Movements, Conflicts, and Change. 25:27-51.

Wade, James B. 1996. "A Community-Level Analysis of Sources and Rates of Technological Variation in the Microprocessor Market." Academy of Management Journal 39 (5): 413-42.

Zaheer, Srilata, and Elaine Mosakowski. 1997. "The Dynamics of the Liability of Foreignness: A Global Study of Survival in Financial Services." Strategic Management Journal 18 (6): 439-64.

Zald, Mayer N., and John D. McCarthy. 1980. "Social Movement Industries: Cooperation and Conflict amongst Social Movement Organizations." Pp. 1-20 in Research in Social Movements, Conflict, and Change, vol. 3, edited by Louis Kriesberg. Greenwich, Conn.: JAI Press. 